the European Ceramic Society

Elsevier Editorial System(tm) for Journal of

Manuscript Draft

Manuscript Number: JECS-D-16-01940R1

Title: Phase transitions and upconversion luminescence in oxyfluoride glass ceramics containing Ba4Gd3F17 nanocrystals

Article Type: Full Length Article

Keywords: upconversion;

luminescence;

Ba4Ga3F17;

oxyfluoride;

glass ceramics

Corresponding Author: Ms. Guna Krieke,

Corresponding Author's Institution: Institute of Solid State Physics

First Author: Guna Krieke

Order of Authors: Guna Krieke; Anatolijs Sarakovskis, Dr.phys; Reinis Ignatans; Jevgenijs Gabrusenoks

Abstract: Novel transparent Er3+ doped oxyfluoride glass-ceramics containing Ba4Gd3F17 nanocrystals were prepared by melt quenching followed by heat treatment of as-prepared glasses. The phase composition and microstructure were investigated by X-ray diffraction (XRD), scanning electron microscopy (SEM) and transmission electron microscopy (TEM) . Intense upconversion luminescence (UCL) was detected. Longer characteristic decay times and splitting of the luminescence bands compared to the precursor glass indicated the incorporation of erbium ions in the crystalline phase. The spectroscopic properties of glass ceramics were compared with single phase cubic and rhombohedral Ba4Gd3F17 ceramics. The unit cell parameters and atomic positions in the rhombohedral phase were calculated using Rietveld refinement. The local environment of Er3+ and the phonon energy of both polymorphs were analyzed using luminescence and Raman spectroscopy. In the glass ceramics, a phase transition from distorted metastable fluorite to ordered rhombohedral Ba4Gd3F17 was observed and resulted in the enhancement of the efficiency of UCL. 
Dear reviewer,

Thank you for your time and efforts spent during the revision of the manuscript.

We believe, that your recommendations will improve the quality of the manuscript.

The detailed response to the comments raised in your revision is given below.

Reviewer \#1: The manuscript covers the study of Ba4Gd3F17 glass-ceramics. An excellent broad spectrum of characterization techniques was used. In the first part of the manuscript the crystallization characteristics are described. Cubic and rhombohedral polymorphs were found to crystallize under different thermal conditions. An exhaustive analysis of the crystalline phases was carried out through XRD and Rietveld analysis. The synthesis of cubic and rhombohedral Ba4Gd3F17 phases through co-precipitation method enables the comparison with the obtained glass-ceramics. The second part is focused on the luminescence properties of the Er3+ doped glass-ceramics. A deep study of the up-conversion mechanism as a function of Er3+ content is put forward. It was possible to discern Er3+ ions in different crystalline sites in both polymorphs.

The results are very well described and the discussion is accordingly well written. I strongly recommend its publication after addressing the following comments:

Fig. 1. The Tg value should be taken from the intersection point of the two extrapolated tangents at the start and at the end of the corresponding peak.

The $T_{g}$ values are calculated from the intersection points, unfortunately due to slight degree of baseline float it is not obvious in the Fig.1. The tangent lines are shown in the figure below.

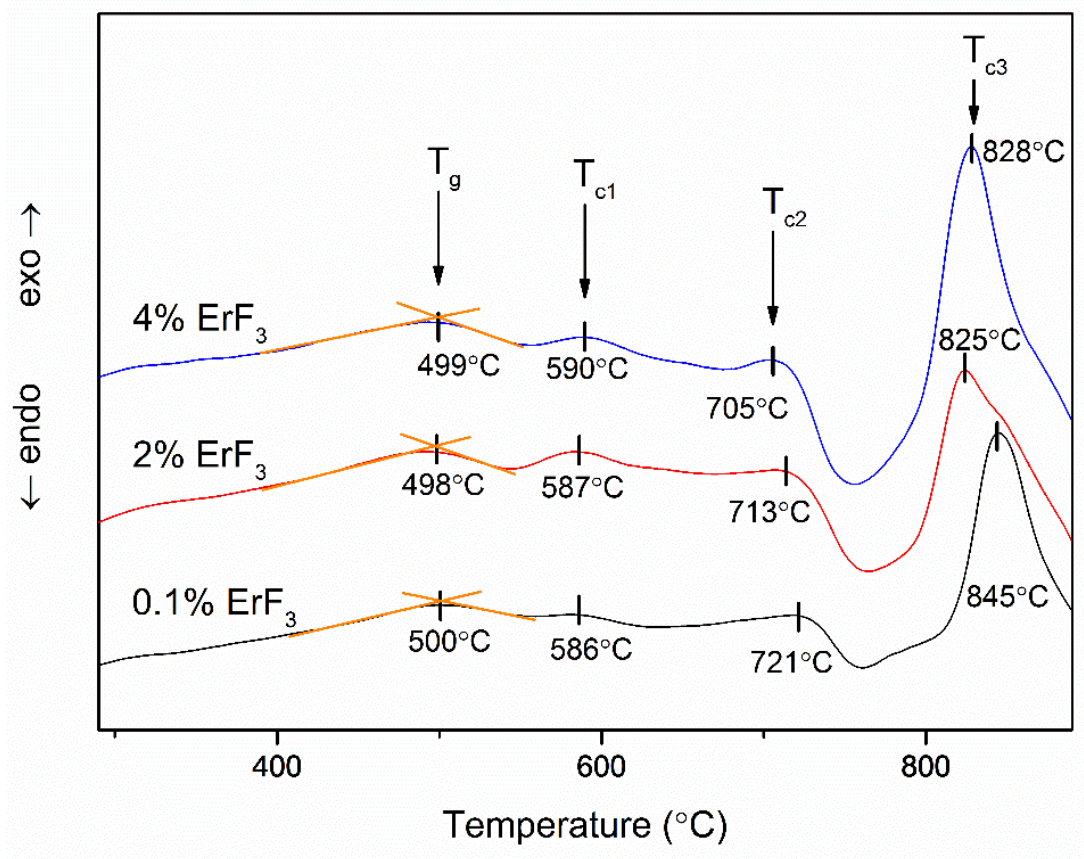

The method for the determination of all characteristic temperatures is now mentioned in the section "Materials and methods". 
Discussion of Fig. 2. In my opinion, the attribution of "crystalline regions" to the slightly higher feature at $26^{\circ}$ in the XRD of the parent glass is not appropriated. You can probably better use terms like "pre-ordered structures" or similar. In the same paragraph: "The heat treatment

of the glass ceramics", should be "The heat treatment of the glasses promotes the formation of fluorite-type....". Please, indicate in Fig.2 what the asterisk * means.

You mentioned that the phase represented through the asterisk * in Fig. 2 indicates the surface crystallization of the glass matrix. How do you know that? Please, explain it. You are not able to know that only from the XRD. Which phases do match with those diffraction peaks?

\section{Thank you for noting!}

We replaced the term "crystalline regions" with pre-ordered structures and changed "glass ceramics" with "glasses".

The asterisk marks two compounds - aluminosilicate nepheline and an unidentified phase. We altered the Fig.2, marked each of these compounds and added the explanation in the text. We agree that the surface crystallization cannot be determined only from XRD, however in these materials the surface crystallization was observed by SEM and the characteristic XRD peaks were not present in the polished samples.

Fig. 11: Please, include in the figure the spectra for the $1 \%$ and $3 \% \mathrm{ErF} 3$ doped samples, to be in agreement with the inset of the figure. Is the spectrum of the base glass also available? It would be useful to compare the spectrum of the glass with those of the glass-ceramics.

The additional luminescence spectra of glass ceramics are added in Fig.11. The luminescence spectra of base glass and glass ceramics are compared in the text.

Fig.14: Please, include in the figure the spectrum of the base glass, according with that mentioned in the text.

The spectrum of the base glass is now included in the Fig.14. 


\title{
Phase transitions and upconversion luminescence in oxyfluoride glass ceramics containing $\mathrm{Ba}_{4} \mathbf{G d}_{3} \mathbf{F}_{17}$ nanocrystals
}

\author{
Guna Krieke, Anatolijs Sarakovskis, Reinis Ignatans, Jevgenijs Gabrusenoks \\ Institute of Solid State Physics, University of Latvia, 8 Kengaraga str., LV-1063, Riga, Latvia.
}

\begin{abstract}
Novel transparent $\mathrm{Er}^{3+}$ doped oxyfluoride glass-ceramics containing $\mathrm{Ba}_{4} \mathrm{Gd}_{3} \mathrm{~F}_{17}$ nanocrystals were prepared by melt quenching followed by heat treatment of as-prepared glasses. The phase composition and microstructure were investigated by X-ray diffraction (XRD), scanning electron microscopy (SEM) and transmission electron microscopy (TEM). Intense upconversion luminescence (UCL) was detected. Longer characteristic decay times and splitting of the luminescence bands compared to the precursor glass indicated the incorporation of erbium ions in the crystalline phase. The spectroscopic properties of glass ceramics were compared with single phase cubic and rhombohedral $\mathrm{Ba}_{4} \mathrm{Gd}_{3} \mathrm{~F}_{17}$ ceramics. The unit cell parameters and atomic positions in the rhombohedral phase were calculated using Rietveld refinement. The local environment of $\mathrm{Er}^{3+}$ and the phonon energy of both polymorphs were analyzed using luminescence and Raman spectroscopy. In the glass ceramics, a phase transition from distorted metastable fluorite to ordered rhombohedral $\mathrm{Ba}_{4} \mathrm{Gd}_{3} \mathrm{~F}_{17}$ was observed and resulted in the enhancement of the efficiency of UCL.
\end{abstract}

KEYWORDS: upconversion, luminescence, $\mathrm{Ba}_{4} \mathrm{Gd}_{3} \mathrm{~F}_{17}$, oxyfluoride, glass ceramics

\section{Introduction}

Recently considerable attention has been devoted to investigation of rare earth (RE) doped materials for upconversion luminescence (UCL) - an anti-Stokes process in which low-energy photons are converted to photons with higher energy [1]. UCL phosphors have demonstrated many potential applications such as upconversion lasers [2,3], multifunctional biological markers and drug delivery systems [4,5], three dimensional displays [6,7], optical sensors [8,9], luminescent layers for solar cells [10,11], data storage [12] and others.

From RE ions, $\mathrm{Er}^{3+}$ is one of the most widely investigated activator for the conversion of near infrared to visible radiation due to favorable ladder-like energy levels and long lifetimes of the emitting states [13]. In fact $\mathrm{Er}^{3+}$ doped materials exhibit the highest upconversion quantum yield in comparison to other RE ion doped materials and organic dyes [14]. The shielding effect of the outer electron shells of trivalent RE ions prevent large variations of energies of the $4 \mathrm{f}$ states for different hosts, nevertheless, erbium has been successfully used both as an activator for UCL and a luminescent probe for the investigation of local structure of lanthanides in crystalline and amorphous materials [15].

The efficiency of the UCL processes depends on the properties of the host material such as phonon energy of the lattice, distances between activator ions and the local symmetry of the activator. Fluoride crystals are extensively investigated as hosts for the UCL due to the low phonon energy that minimizes the non-radiative relaxations in the material and therefore 
enables an efficient UCL $[13,16]$. Among other fluorides, $\mathrm{BaF}_{2}$ is a suitable host for the UCL due to lower phonon energy than other alkaline earth fluorides and formation of heterovalent fluorite-type solid solutions with all RE ions [17,18]. Unfortunately, RE activators tend to form clusters in $\mathrm{BaF}_{2}$ lattice even if the dopant content is as low as $0.05 \mathrm{~mol} \%$, leading to cross-relaxation (CR) between activators and reduction of the efficiency of radiative processes [19]. As the result, complex RE doped systems such as $\mathrm{BaF}_{2}-\mathrm{REF}_{3}(\mathrm{RE}=\mathrm{La}, \mathrm{Gd}, \mathrm{Y}, \mathrm{Lu})$ have to be considered. In these quasi-binary systems several compounds have been detected: monoclinic and orthorhombic $\mathrm{BaRE}_{2} \mathrm{~F}_{8}$, two ordered phases (tetragonal and rhombohedral) with distorted fluorite structure and solid solutions with tysonite and fluorite structure [18]. RE doped single crystals of monoclinic $\mathrm{BaRE}_{2} \mathrm{~F}_{8}$ are widely investigated and are proposed as excellent laser hosts [20,21]. Considerable attention is also devoted to the investigation of fluorite solid solutions [22,23], however there is limited information about optical properties of the other compounds.

$\mathrm{BaF}_{2}-\mathrm{REF}_{3}$ compounds have been extensively studied as nanocrystals in various oxyfluoride glass ceramics. Efficient UCL processes in glass ceramics containing fluorite type phases such as $\mathrm{Ba}_{2} \mathrm{LaF}_{7}$ [24], $\mathrm{BaYF}_{5}$ [25], $\mathrm{BaYbF}_{5}$ [26] and $\mathrm{Ba}_{1-\mathrm{x}} \mathrm{Lu}_{\mathrm{x}} \mathrm{F}_{2+\mathrm{x}}$ [27]. Oxyfluoride glass ceramics are excellent candidates for applications in which transparency is required. Recently we have developed new transparent glass ceramics in which nanocrystalline rhombohedral $\mathrm{Ba}_{4} \mathrm{Y}_{3} \mathrm{~F}_{17}$ can be prepared [28], however isostructural $\mathrm{Ba}_{4} \mathrm{RE}_{3} \mathrm{~F}_{17}$ are formed in other binary $\mathrm{BaF}_{2}-\mathrm{REF}_{3}$ $(\mathrm{RE}=\mathrm{Gd}-\mathrm{Lu})$ systems [29].

In this work we report new $\mathrm{Er}^{3+}$ doped glass ceramics containing $\mathrm{Ba}_{4} \mathrm{Gd}_{3} \mathrm{~F}_{17}$ nanocrystals. The structure of cubic and rhombohedral $\mathrm{Ba}_{4} \mathrm{Gd}_{3} \mathrm{~F}_{17}$ is discussed. The phase transition and UCL processes in the glass ceramics are analyzed.

\section{Materials and methods}

Glasses with the composition of $17 \mathrm{Na}_{2} \mathrm{O}-9 \mathrm{BaF}_{2}-(8-\mathrm{x}) \mathrm{GdF}_{3}-\mathrm{xErF}_{3}-6 \mathrm{Al}_{2} \mathrm{O}_{3}-60 \mathrm{SiO}_{2}(\mathrm{x}=0.1-4)$ in mol\% were prepared from high purity raw materials. The batches of $9 \mathrm{~g}$ were melted in covered corundum crucibles at $1500^{\circ} \mathrm{C}$ for $30 \mathrm{~min}$ in air atmosphere followed by the casting of the melt in stainless steel mold. The glass ceramics were obtained after isothermal heat treatment of the glass at $600-750^{\circ} \mathrm{C}$ for $5 \mathrm{~h}$.

Additionally, polycrystalline $\mathrm{Ba}_{4} \mathrm{Gd}_{3} \mathrm{~F}_{17}$ undoped and doped with $0.5 \% \mathrm{ErF}_{3}$ were prepared by co-precipitation from aqueous solutions. Analytical grade rare earth $\left(1.5 \mathrm{mmol} \mathrm{GdCl}_{3} \cdot 5 \mathrm{H}_{2} \mathrm{O}\right.$ for the undoped or $1.4925 \mathrm{mmol} \mathrm{GdCl}_{3} \cdot 5 \mathrm{H}_{2} \mathrm{O}$ and $0.0075 \mathrm{mmol} \mathrm{Er}\left(\mathrm{NO}_{3}\right)_{3} \cdot 5 \mathrm{H}_{2} \mathrm{O}$ for the doped samples) and barium ( $2 \mathrm{mmol} \mathrm{BaCl}_{2} \cdot 2 \mathrm{H}_{2} \mathrm{O}$ ) salts were dissolved in $10 \mathrm{ml}$ deionized water. The $\mathrm{Ba}_{4} \mathrm{RE}_{3} \mathrm{~F}_{17}$ was precipitated by addition of $37.5 \mathrm{mmol} \mathrm{NH}_{4} \mathrm{~F}$ and thoroughly stirred for 3 h. The product was collected by filtration and dried in air. The as-prepared low-temperature cubic form was annealed at $150^{\circ} \mathrm{C}$ in $\mathrm{He} / \mathrm{F}_{2}$ flow for $1 \mathrm{~h}$ to remove adsorbed water and $\mathrm{OH}^{-}$ impurities followed by heat treatment at $600^{\circ} \mathrm{C}$ in Ar flow for $1 \mathrm{~h}$ to improve the crystallinity of the cubic polymorph or $800^{\circ} \mathrm{C}$ for $1 \mathrm{~h}$ to produce the rhombohedral $\mathrm{Ba}_{4} \mathrm{Gd}_{3} \mathrm{~F}_{17}$.

The differential thermal analysis (DTA) was carried out in a differential thermal analyzer (Shimadzu Corp. DTG-60) at a heating rate of $10 \mathrm{~K} / \mathrm{min}$ with $\mathrm{Al}_{2} \mathrm{O}_{3}$ as a reference. The glass 
transition temperature was determined as an intersection point of tangent lines from the baseline and the endothermic slope. All characteristic crystallization temperatures were assigned as the maxima of the exothermic effects instead of the onset temperatures due to partial overlapping of the peaks.

X-ray diffraction data was obtained by PANalytical X'Pert Pro diffractometer using $\mathrm{Cu} \mathrm{K}_{\alpha}$ tube operated at $40 \mathrm{kV}$ and $30 \mathrm{~mA}$. The Rietveld analysis was performed using Profex software [30] and crystal structure data of rhombohedral $\mathrm{Ba}_{4} \mathrm{Y}_{3} \mathrm{~F}_{17}$ reported in [31]. For visualization of the crystal structure software Vesta [32] was used.

The microstructure of the glass ceramics was analyzed by scanning electron microscopy (SEM) using Tescan Lyra operated at $15 \mathrm{kV}$ and transmission electron microscopy (TEM) using Tecnai G2 F20 operated at $200 \mathrm{kV}$. For SEM characterization, uncoated, fractured surfaces of the glass and glass ceramics were used.

The Raman spectra were measured with $4 \mathrm{~cm}^{-1}$ resolution using a 1403 double grating SpexRamalog spectrophotometer with a conventional photon counting system. The spectra were excited with the $671 \mathrm{~nm}$ laser.

Luminescence was excited by a wavelength tunable pulsed solid state laser Ekspla NT342/3UV and temperature controlled continuous wave $(\mathrm{CW})$ laser diode $\left(\lambda_{\mathrm{em}}=975 \mathrm{~nm}\right.$, variable radiant power up to $1 \mathrm{~W}$ ). The emission signal was detected by Andor DU-401-BV CCD camera coupled to Andor SR-303i-B spectrometer. Luminescence decay was measured using a photomultiplier tube and digital oscilloscope Tektronix TDS 684A. Low temperature measurements were performed using Advanced Research Systems DE202 N cold finger type He cryostat.

\section{Results and discussion}

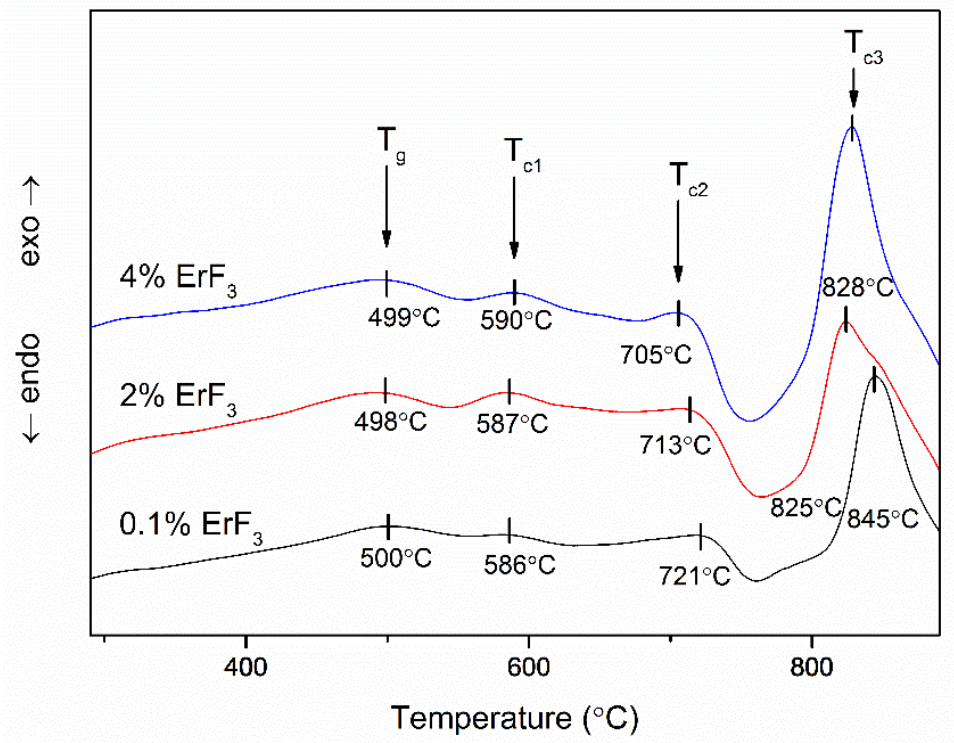

Fig. 1. DTA curve of glass samples containing 0.1, 2 and $4 \% \mathrm{ErF}_{3}$. 
The DTA curve of the as-quenched glass is presented in Fig. 1. An endothermic effect located at $499 \pm 1^{\circ} \mathrm{C}$ is ascribed to glass transition $\left(\mathrm{T}_{\mathrm{g}}\right)$. No significant deviation of $\mathrm{T}_{\mathrm{g}}$ can be detected for glasses with different $\mathrm{ErF}_{3}$ content indicating that the change of the $\mathrm{GdF}_{3} / \mathrm{ErF}_{3}$ ratio has no considerable effect on the viscosity of these glasses. Three exothermic effects are detected with the peak temperature located at $588 \pm 2^{\circ} \mathrm{C}, 713 \pm 7^{\circ} \mathrm{C}$ and $833 \pm 9^{\circ} \mathrm{C}$. The first two $\left(\mathrm{T}_{\mathrm{c} 1}\right.$ and $\left.T_{\mathrm{c} 2}\right)$ are ascribed to the crystallization of fluoride phases while the third $\left(\mathrm{T}_{\mathrm{c} 3}\right)$ represents the bulk crystallization of the aluminosilicate glass matrix. No significant changes of the $T_{c 1}$ and $\mathrm{T}_{\mathrm{c} 2}$ can be detected with the increase of $\mathrm{ErF}_{3}$ content in glass matrix suggesting a similar crystallization behavior and phase composition of the glass ceramics obtained after identical heat treatment.

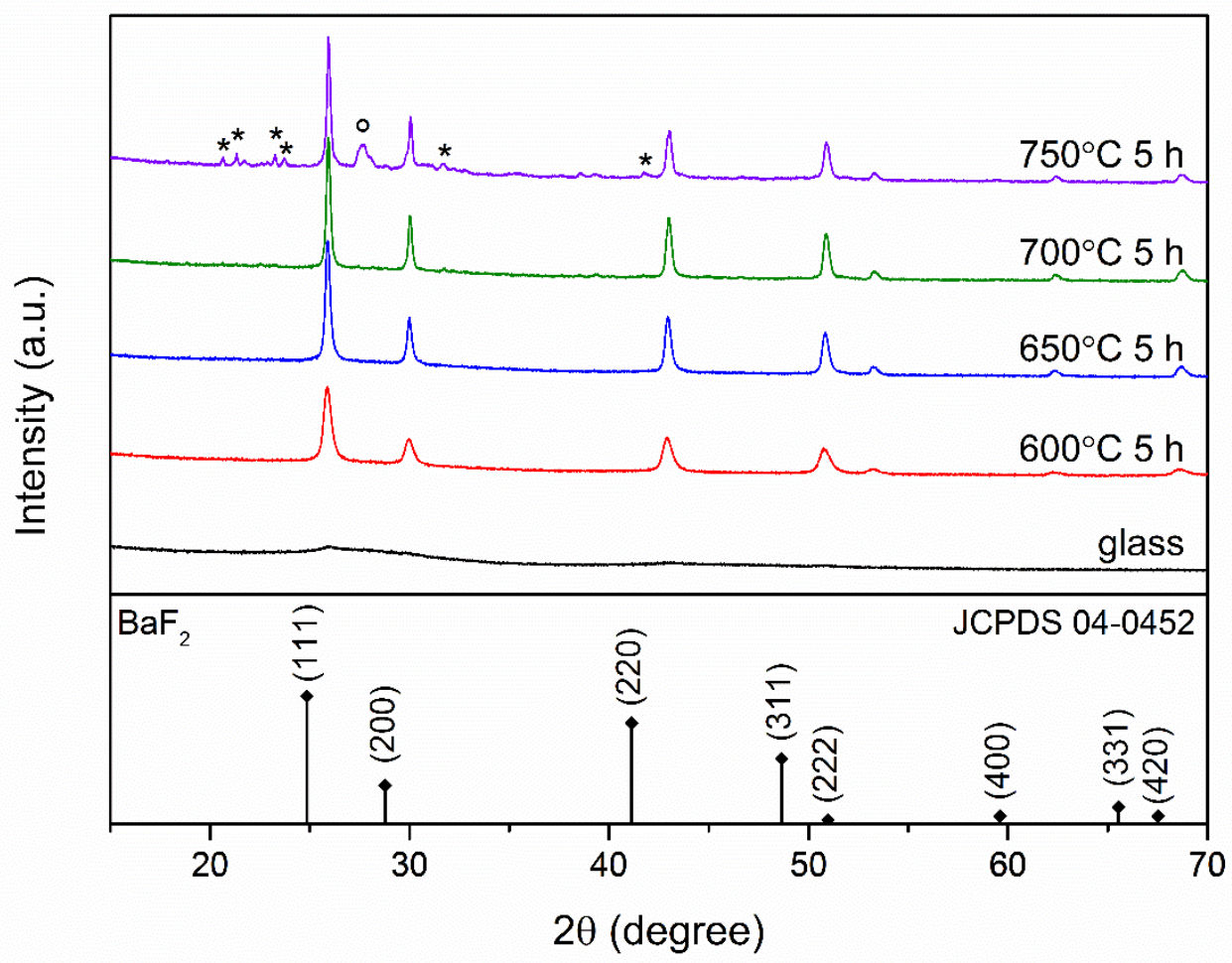

Fig. 2. XRD patterns of oxyfluoride glass doped with $0.1 \% \mathrm{ErF}_{3}$ heat treated at different temperatures for $5 \mathrm{~h}\left(*\right.$ indicate the most intensive peaks of aluminosilicate nepheline, ${ }^{\circ}$ marks an unidentified phase).

The XRD patterns of the parent glass and glass ceramics doped with $0.1 \% \mathrm{ErF}_{3}$ heat treated at the temperatures in the range from $600^{\circ} \mathrm{C}$ to $750^{\circ} \mathrm{C}$ for $5 \mathrm{~h}$ are presented in Fig. 2. No sharp diffraction peaks can be detected in the parent glass, however slightly higher intensity around $26^{0}(2 \theta)$ corresponding to the most intense XRD peak of fluorite phase (111) plane as well as SEM (Fig. 3) and luminescence data (Fig. 17) discussed later in the text suggest that preordered structures are already present in the glass after the melt-quenching. The heat treatment of the glasses promotes the formation of fluorite-type compound isostructural with $\mathrm{BaF}_{2}$. The exothermic effect associated with the crystallization of this compound can be detected in the DTA curves (see Fig. 1). A considerable shift of the XRD peaks suggests incorporation of ions 
with smaller ionic radii in the fluorite lattice. In oxyfluoride glasses $\mathrm{RE}^{3+}$ ions usually are segregated in the crystalline phase [33], therefore we expect the formation of fluorite-type solid solutions with general composition of $\mathrm{Ba}_{1-\mathrm{x}} \mathrm{Gd}_{\mathrm{x}} \mathrm{F}_{2+\mathrm{x}}$. The lattice parameter of the nanocrystals $\mathrm{a}=5.955 \pm 0.005 \AA$ is in a good agreement with a metastable fluorite phase with chemical composition $\mathrm{Ba}_{4} \mathrm{Gd}_{3} \mathrm{~F}_{17}$ [29]. The narrowing of the diffraction peaks with the increase of the heat treatment suggests the growth of the nanocrystals. Some additional peaks (marked with $*$ and ${ }^{\circ}$ ) can be observed after the heat treatment at $750^{\circ} \mathrm{C}$ for $5 \mathrm{~h}$ indicating the crystallization of nepheline $\left(\mathrm{NaAlSiO}_{4}\right)$ and an unidentified phase. The formation of aluminosilicates was observed only on the surface of the glass ceramics and could be easily removed by polishing.
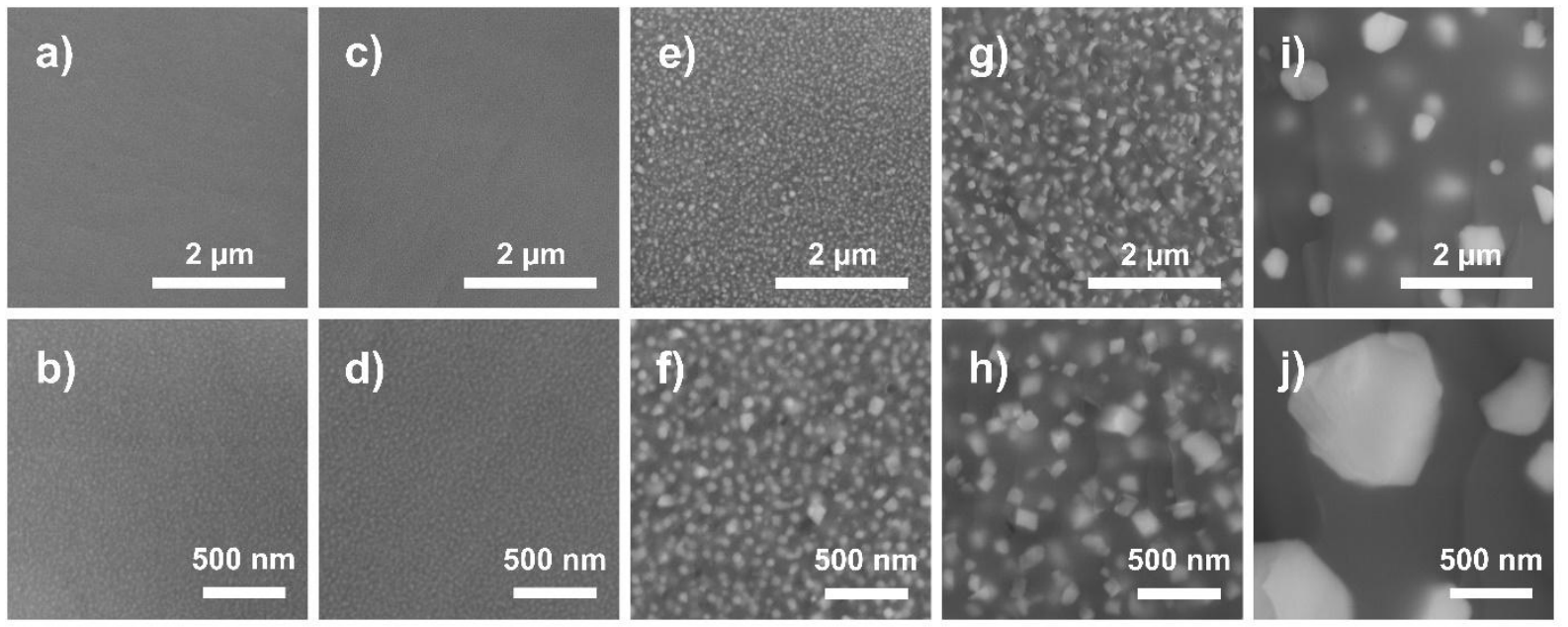

Fig. 3. SEM micrographs of a,b) glass and glass ceramics heat treated at c,d) $600^{\circ} \mathrm{C}$, e,f) $650^{\circ} \mathrm{C}$, g,h) $700^{\circ} \mathrm{C}$ and i,j) $750^{\circ} \mathrm{C}$ for $5 \mathrm{~h}$.

Fig. 3 shows SEM micrographs of the fractured surfaces of the glass and glass ceramics heat treated in the temperature range $600-750^{\circ} \mathrm{C}$ for $5 \mathrm{~h}$. The lighter section represents fluoride particles enriched with heavy element ions $\left(\mathrm{Ba}^{2+}\right.$ and $\left.\mathrm{RE}^{3+}\right)$ while the darker sections are glass matrix containing lighter element ions $\left(\mathrm{Na}^{+}, \mathrm{Si}^{4+}, \mathrm{Al}^{3+}\right)$. The separation of light and heavy element ions is detectable also in the glass sample indirectly suggesting a spontaneous crystallization during the cooling of the melt. In all glass ceramics the crystalline particles are homogeneously distributed in the glass matrix. Heat treatment at higher temperature results in the increased size of the nanocrystals, however the number of crystallites per volume is considerably reduced, suggesting the dissolution of the smaller particles in glass matrix therefore enabling the growth of larger crystals.

In oxyfluoride glass ceramics formation of silica-rich layer, due to the incorporation of glass modifiers such as alkali, alkaline earth and rare earth ions in the crystalline phase, is often observed [34-36]. This layer acts as a diffusion barrier and suppresses the growth of nanocrystals. In the present study the size of the crystals can be varied from few nm to several hundred $\mathrm{nm}$ depending on the temperature during the heat treatment. Furthermore, a change in the morphology from spherical nanocrystals to rhombohedral prisms can be observed suggesting a relatively low viscosity of the glass matrix. In these glass ceramics the formation 
of fluoride crystals reduce the $\mathrm{Ba}^{2+}$ content in the glassy matrix, however $\mathrm{Na}^{+}$ions are incorporated in the amorphous glass, therefore the viscosity of the base glass is rather low. This effect enables an efficient ionic diffusion and a rapid growth of rather large fluoride crystals in the glass matrix.
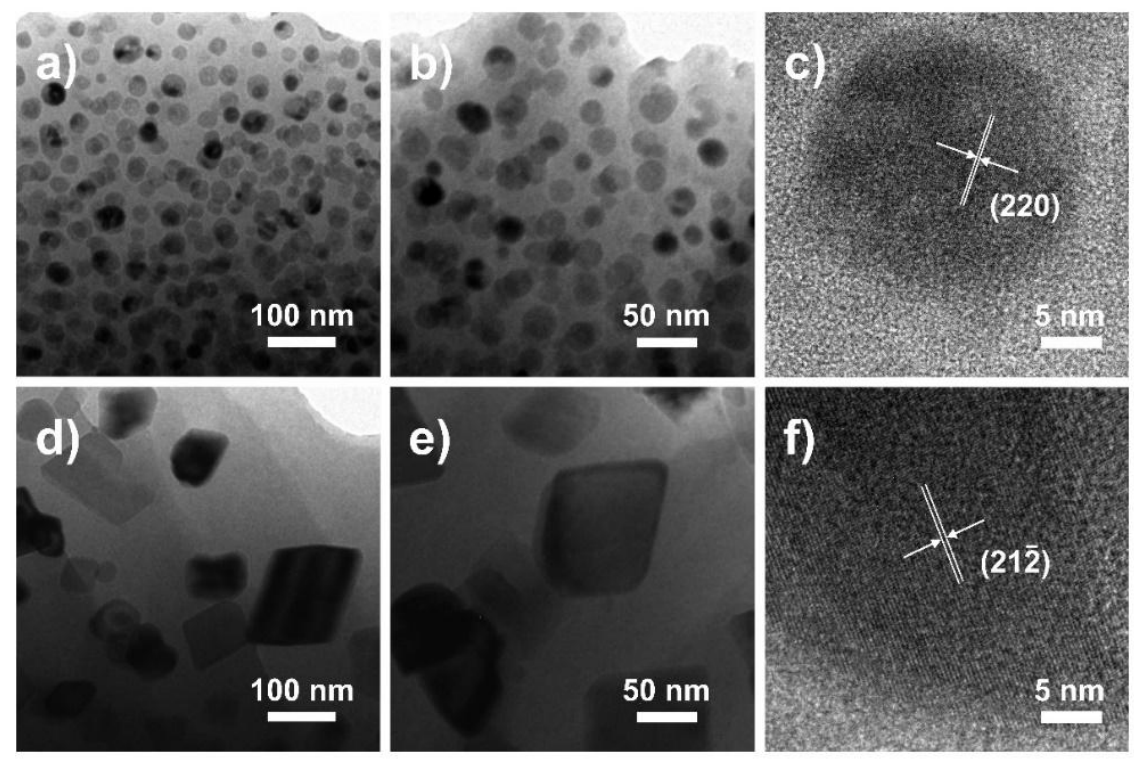

Fig. 4. TEM micrographs of glass ceramics heat treated at a-c) $600^{\circ} \mathrm{C}$ and d-f) $700^{\circ} \mathrm{C}$ for $5 \mathrm{~h}$.

The TEM micrographs shown in Fig. 4 illustrate changes in the morphology after heat treatment at $600^{\circ} \mathrm{C}$ and $700^{\circ} \mathrm{C}$. Spherical single crystals with average size of $27 \pm 7 \mathrm{~nm}$ homogeneously dispersed in amorphous glass matrix are observed after the heat treatment at $600^{\circ} \mathrm{C}$ for $5 \mathrm{~h}$. The interplanar distance of an individual nanocrystal (Fig. $4 \mathrm{c}$ ) is $0.211 \mathrm{~nm}$ ascribed to (220) plane of fluorite lattice. The heat treatment at $700^{\circ} \mathrm{C}$ for $5 \mathrm{~h}$ resulted in the formation of rhombohedral single-crystalline prisms with average size up to $100 \mathrm{~nm}$. The rhombohedral morphology of the nanocrystals is unusual and indicates ordering in the fluorite phase. Two distinct ordered phases have been observed in $\mathrm{BaF}_{2}-\mathrm{GdF}_{3}$ binary system tetragonal and rhombohedral [18]. Both XRD and SEM data suggest the formation of the latter compound. The interplanar distance of individual single crystal (see Fig. 4 f) can be ascribed to $(21 \overline{2})$ plane assuming rhombohedral distortion in the fluorite lattice. In order to investigate the structure of this phase and identify the phase transition in the glass ceramics, single phase metastable cubic and ordered rhombohedral polycrystalline $\mathrm{Ba}_{4} \mathrm{Gd}_{3} \mathrm{~F}_{17}$ were prepared and analyzed.

In non-equilibrium systems metastable fluorite type solid solutions instead of the thermodynamically stable phases are often obtained. By using co-precipitation in water, formation of cubic instead of rhombohedral $\mathrm{Ba}_{4} \mathrm{RE}_{3} \mathrm{~F}_{17}$ has been observed [29] and it is in a good agreement with our results. 

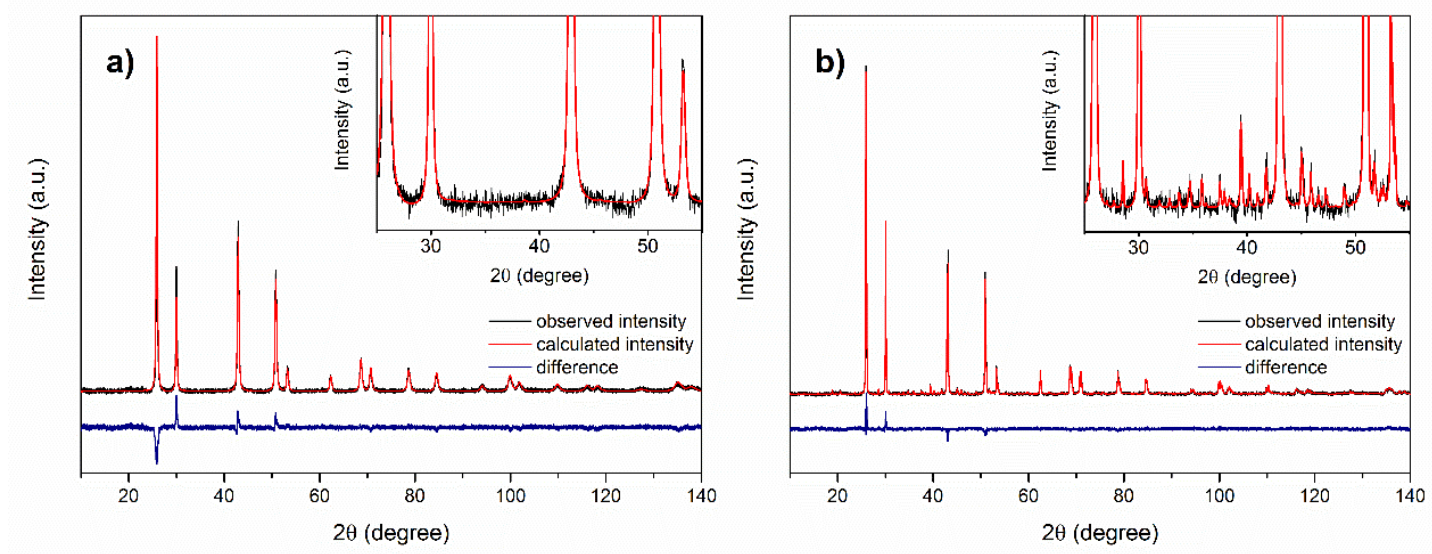

Fig. 5. Experimental and calculated XRD patterns of $\mathrm{Ba}_{4} \mathrm{Gd}_{3} \mathrm{~F}_{17}$ after heat treatment at a) $600^{\circ} \mathrm{C}$ and b) $800^{\circ} \mathrm{C}$ for $1 \mathrm{~h}$. Insets: enlarged sections of XRD patterns.

Fig. 5 shows experimental and calculated XRD patterns of polycrystalline $\mathrm{Ba}_{4} \mathrm{Gd}_{3} \mathrm{~F}_{17}$ samples obtained after the heat treatment at $600^{\circ} \mathrm{C}$ and $800^{\circ} \mathrm{C}$ for $1 \mathrm{~h}$. The observed reflections of low temperature sample (Fig. 5 a) could be indexed as a cubic fluorite type lattice (space group $\mathrm{Fm} \overline{3} \mathrm{~m}$ ) with unit cell parameter $\mathrm{a}=5.957 \AA$ and no additional peaks characteristic of distortion in the structure could be detected. A structural model of cubic $\mathrm{BaF}_{2}$ was used for the Rietveld refinement, and this model could be fitted to the experimental data acceptably (goodness of fit $\chi^{2}=2.42$ ). However, there are many experimental evidences of clustering of rare earth ions in the alkaline earth fluorite crystals that incorporate into fluorite lattice in blocks instead of randomly occupying cationic positions [37-39]. In $\mathrm{BaF}_{2}-\mathrm{REF}_{3}$ system $\mathrm{RE}$ ions from $\mathrm{Pr}^{3+}$ to $\mathrm{Lu}^{3+}$ tend to form octahedral $\mathrm{RE}_{6} \mathrm{~F}_{36-37}$ clusters with one or two excess fluorine anions located in the center of the cluster. These clusters are surrounded by $\mathrm{Ba}^{2+}$ ions in larger cubic structural elements [37]. Schematic representation of $\mathrm{Gd}_{6} \mathrm{~F}_{36-37}$ clusters and $\mathrm{Ba}_{8} \mathrm{Gd}_{6} \mathrm{~F}_{68-69}$ blocks expected to appear in the $\mathrm{BaF}_{2}-\mathrm{GdF}_{3}$ fluorite phases are shown in Fig. 6.

a)

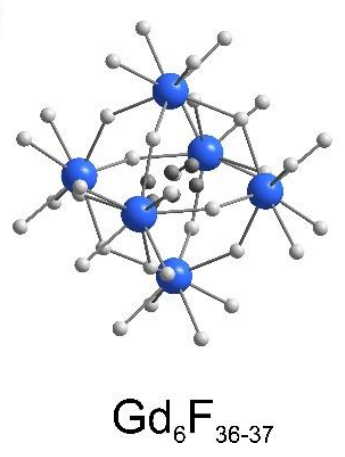

b)

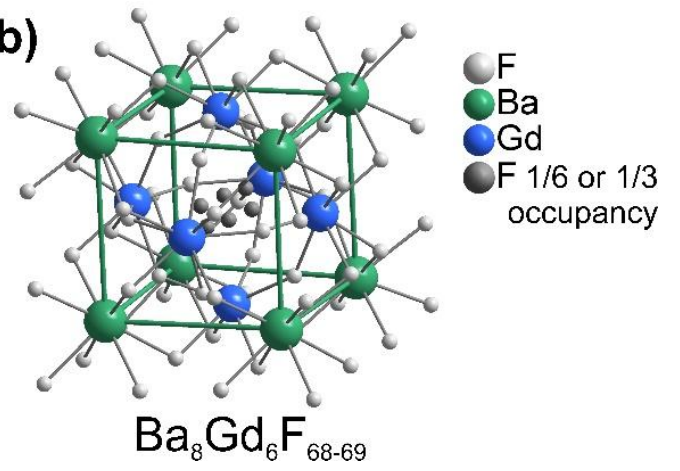

Fig. 6. Rare earth clusters in fluorite type $\mathrm{BaF}_{2}-\mathrm{GdF}_{3}$ solid solutions.

The XRD pattern of the polycrystalline ceramics obtained after heat treatment at $800^{\circ} \mathrm{C}$ (see Fig. $5 \mathrm{~b}$ ) is similar to the low temperature one, however a splitting of several peaks and additional superstructure peaks can be detected indicating an ordering of the structural elements in the fluorite lattice. The XRD pattern was refined using atomic positions of 
rhombohedral $\mathrm{Ba}_{4} \mathrm{Y}_{3} \mathrm{~F}_{17}$. As the result, rhombohedrally distorted fluorite cell with $\mathrm{a}=\mathrm{b}=11.144$ $\AA$ and $\mathrm{c}=20.508 \AA$ was obtained, which is in a good agreement with the theoretical model (goodness of fit $\chi^{2}=1.62$ ). The atomic parameters of the structure model are listed in table 1 .

Table 1.

Atomic parameters of the structure model (space-group: $\mathrm{R} \overline{3}$ (No. 148))

\begin{tabular}{cccccccc}
\hline Atom & Ox & $\begin{array}{c}\text { Wyckoff } \\
\text { position }\end{array}$ & $\begin{array}{c}\text { Site } \\
\text { symmetry }\end{array}$ & $\mathrm{x}$ & $\mathrm{y}$ & $\mathrm{z}$ & Occ. \\
\hline $\mathrm{F}$ & -1 & $\mathrm{f} 18$ & 1 & 0.9192 & 0.9302 & 0.4945 & 0.1666 \\
$\mathrm{Ba}$ & 2 & $\mathrm{f} 18$ & 1 & 0.2275 & 0.0303 & 0.0850 & 1 \\
$\mathrm{~F}$ & -1 & $\mathrm{f} 18$ & 1 & 0.0391 & 0.7917 & 0.0465 & 1 \\
$\mathrm{~F}$ & -1 & $\mathrm{f} 18$ & 1 & 0.4685 & 0.0770 & 0.0373 & 1 \\
$\mathrm{~F}$ & -1 & $\mathrm{f} 18$ & 1 & 0.4270 & 0.2848 & 0.1138 & 1 \\
$\mathrm{Gd}$ & 3 & $\mathrm{f} 18$ & 1 & 0.0856 & 0.6141 & 0.0820 & 1 \\
$\mathrm{~F}$ & -1 & $\mathrm{f} 18$ & 1 & 0.1985 & 0.4977 & 0.0525 & 1 \\
$\mathrm{~F}$ & -1 & $\mathrm{a} 3$ & -3 & 0 & 0 & 0 & 1 \\
$\mathrm{Ba}$ & 2 & $\mathrm{c} 6$ & 3 & 0 & 0 & 0.2654 & 1 \\
$\mathrm{~F}$ & -1 & $\mathrm{f} 18$ & 1 & 0.2452 & 0.3461 & 0.1728 & 1 \\
$\mathrm{~F}$ & -1 & $\mathrm{c} 6$ & 3 & 0 & 0 & 0.1288 & 1 \\
\hline
\end{tabular}

The crystal structure of $\mathrm{Ba}_{4} \mathrm{Gd}_{3} \mathrm{~F}_{17}$ represented in Fig. 7 is composed of $\mathrm{Ba}_{8} \mathrm{Gd}_{6} \mathrm{~F}_{68}$ structural units shown in Fig. 6 b linked together by fluorine atoms (Ba-F bonds are omitted for clarity).

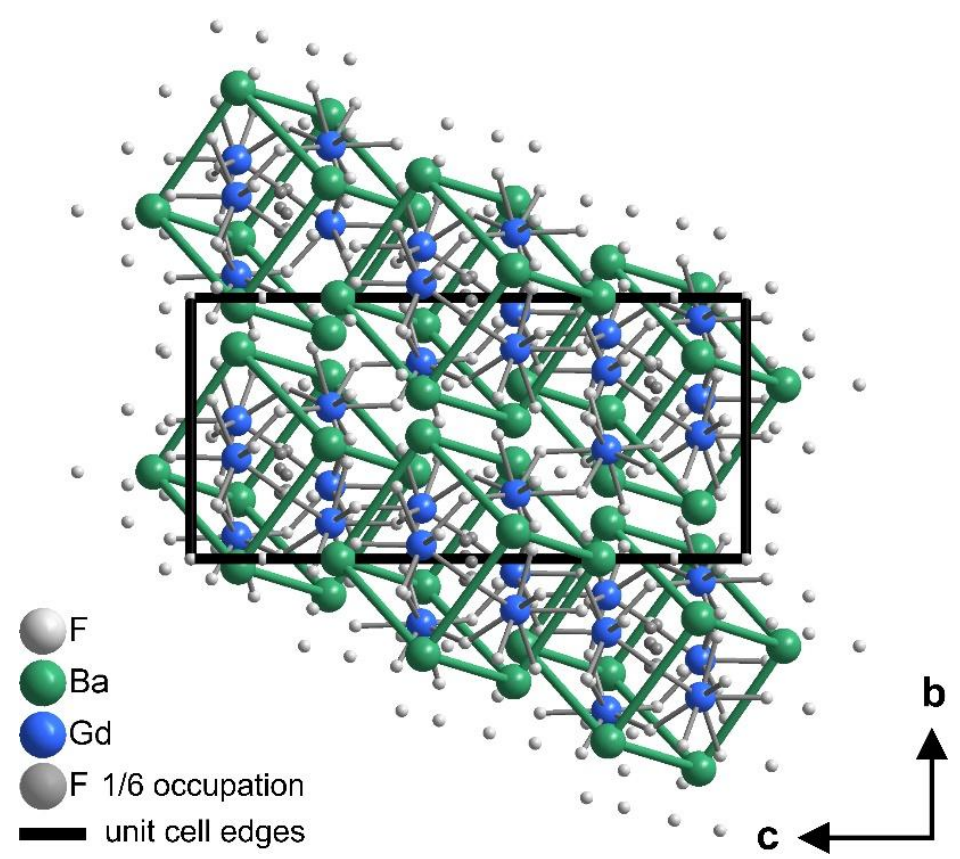

Fig. 7. Crystal structure of rhombohedral $\mathrm{Ba}_{4} \mathrm{Gd}_{3} \mathrm{~F}_{17}$, projection along a axis.

Three distinct cationic positions are determined - two kinds of crystallographically distinct Ba and one Gd position. When a RE activator is introduced in the crystalline lattice, it is expected 
to replace $\mathrm{Gd}^{3+}$ ions due to the similarities in ionic radii and oxidation states. The low local symmetry $\left(\mathrm{C}_{1}\right)$ of $\mathrm{Gd}^{3+}$ sites is favorable for UCL processes. The shortest distances between $\mathrm{RE}$ ions $(4.07 \AA)$ are larger than in the most fluoride hosts such as $\mathrm{LiYF}_{4}(2.58 \AA$ [40]), $\beta$ $\mathrm{NaYF}_{4}\left(3.33 \AA\right.$ [41]) and $\mathrm{BaY}_{2} \mathrm{~F}_{8}(3.70 \AA$ [42]), therefore the efficiency of CR processes is expected to be lower even for high activator concentrations.

The phase transition in such compounds is accompanied only by ordering or disordering of the structural elements shown in Fig. 6 rather than destruction of clusters [37]. We are assuming a similar structure in cubic $\mathrm{Ba}_{4} \mathrm{Gd}_{3} \mathrm{~F}_{17}$ consisting of $\mathrm{Ba}_{8} \mathrm{Gd}_{6} \mathrm{~F}_{68}$ structural units that are disordered in relation to one another, therefore the low local symmetry and large distances between RE ions can also be expected.

Fluorides exhibit low phonon energy, which is a crucial parameter for UCL hosts. Unfortunately, up till now there are no reports about phonon energy of ordered $\mathrm{BaF}_{2}-\mathrm{REF}_{3}$ fluorite derived compounds. In this work the maximal and effective phonon energy of $\mathrm{Ba}_{4} \mathrm{Gd}_{3} \mathrm{~F}_{17}$ was obtained from Raman spectra shown in Fig. 8.

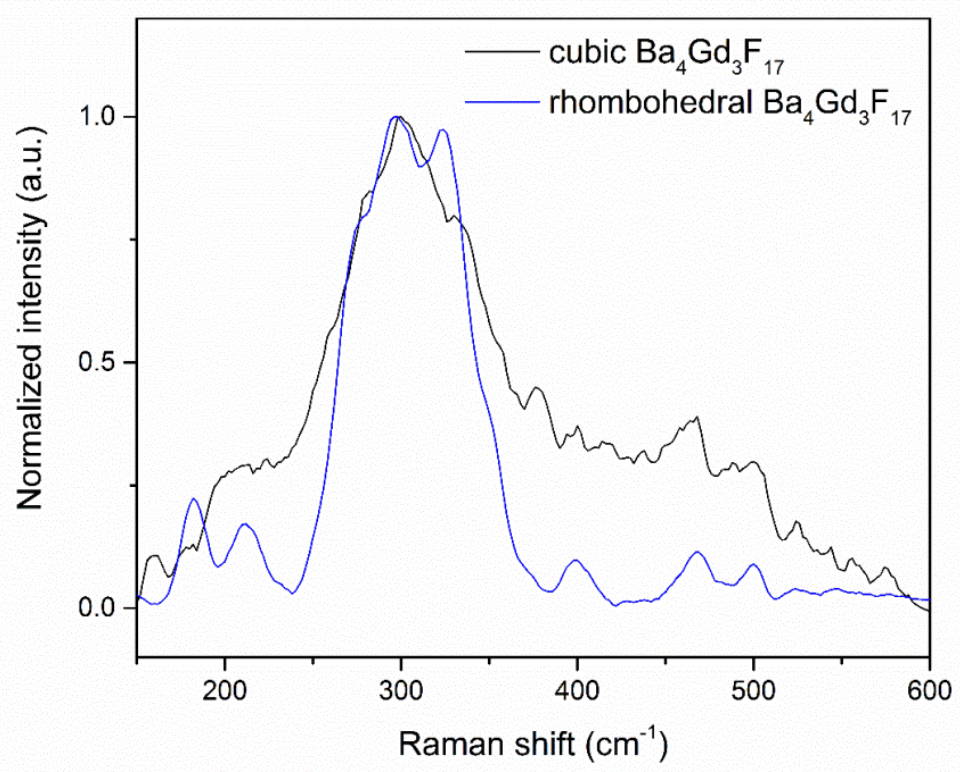

Fig. 8. Raman spectra of cubic and rhombohedral $\mathrm{Ba}_{4} \mathrm{Gd}_{3} \mathrm{~F}_{17}$.

Similar Raman spectra are detected for both rhombohedral and cubic phases, suggesting a similar structure of both polymorphs. Slightly broader and less resolved peaks of the cubic $\mathrm{Ba}_{4} \mathrm{Gd}_{3} \mathrm{~F}_{17}$ are probably attributed to the distortion in the crystalline lattice. The average phonon energy of $\mathrm{Ba}_{4} \mathrm{Gd}_{3} \mathrm{~F}_{17}$ is $340 \mathrm{~cm}^{-1}$ for the cubic and $310 \mathrm{~cm}^{-1}$ for the rhombohedral phase. The highest phonon frequency is located at $\sim 500 \mathrm{~cm}^{-1}$. It is comparable to $\beta-\mathrm{NaYF}_{4}-\mathrm{a}$ low-phonon host considered to be the most efficient matrix for UCL [43]. The lower phonon energy of rhombohedral phase is favorable for UCL and is expected to reduce the nonradiative processes of erbium ions. 
In the glass ceramics the thermal treatment of the metastable cubic $\mathrm{Ba}_{4} \mathrm{Gd}_{3} \mathrm{~F}_{17}$ should promote the phase transition to the rhombohedral polymorph. This transition should result in the decrease of the enthalpy of the sample and be detectable as an exothermic thermal effect. An indication of a phase transition in these materials is the presence of exothermic effect $\mathrm{T}_{\mathrm{c} 2}$ ( $\mathrm{see}$ Fig. 1) observed in all investigated glasses. However, no significant changes in XRD patterns can be detected in this temperature range (see Fig. 2). The relatively small size of the nanocrystals, low intensity of the superstructure peaks of rhombohedral $\mathrm{Ba}_{4} \mathrm{Gd}_{3} \mathrm{~F}_{17}$ as well as additional phase impurities observed in the glass ceramics heat treated at $750^{\circ} \mathrm{C}$ make the identification of the ordering of the fluorite phase difficult in these materials.

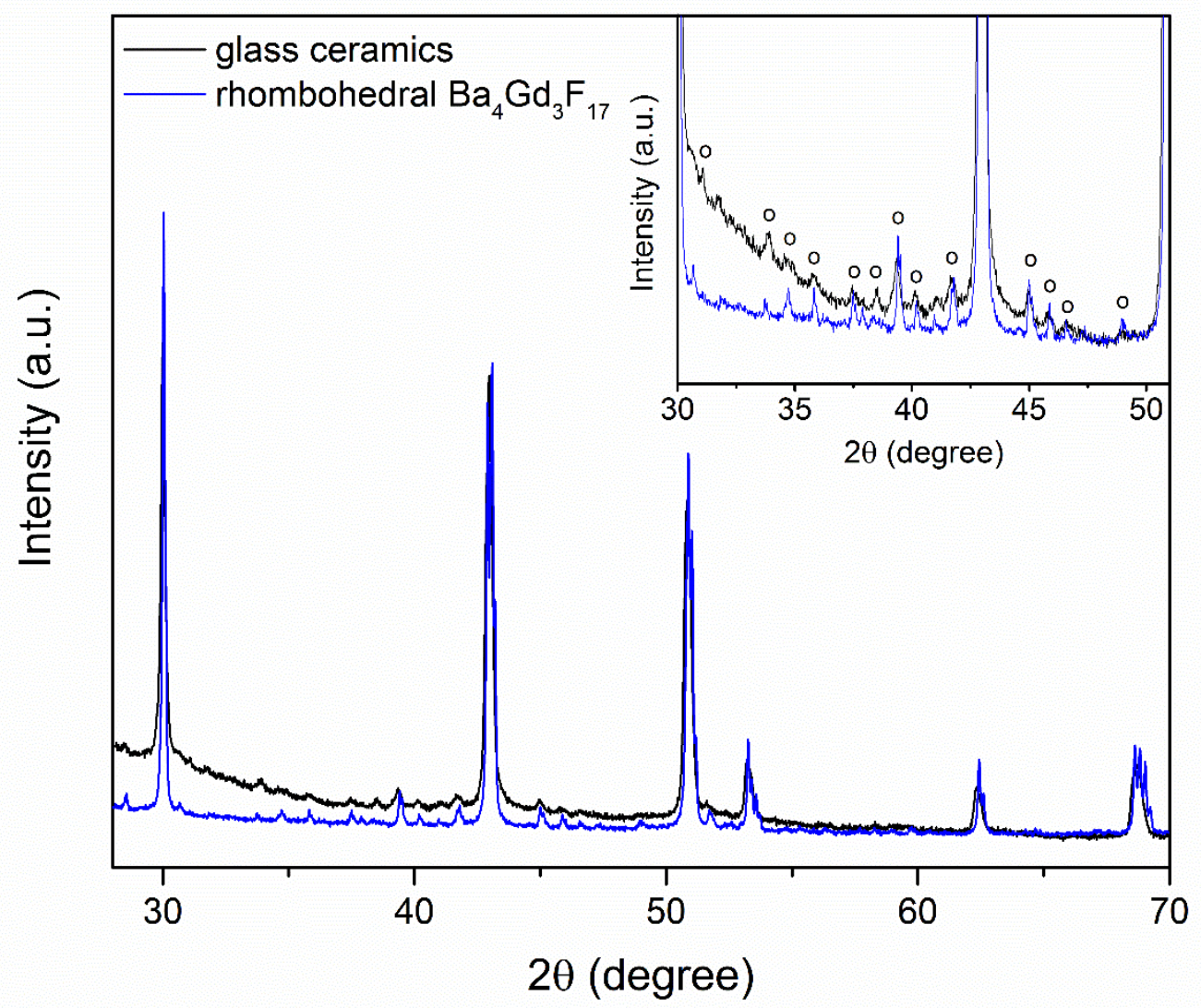

Fig. 9. The comparison of XRD patterns of glass ceramic heat treated at $725^{\circ} \mathrm{C}$ for $5 \mathrm{~h}$ and rhombohedral $\mathrm{Ba}_{4} \mathrm{Gd}_{3} \mathrm{~F}_{17}$. The superstructure reflections are marked with $\bigcirc$. Inset: enlarged sections of XRD patterns.

Fig. 9 shows XRD patterns of the glass ceramics heat treated at $725^{\circ} \mathrm{C}$ for $5 \mathrm{~h}$ compared with rhombohedral $\mathrm{Ba}_{4} \mathrm{Gd}_{3} \mathrm{~F}_{17}$. Undeniable similarities in XRD patterns can be observed. Several low intensity superstructure peaks characteristic to rhombohedral $\mathrm{Ba}_{4} \mathrm{Gd}_{3} \mathrm{~F}_{17}$ can be detected also in the glass ceramic sample (marked with o in the inset of Fig. 9) indicating the rhombohedral distortion in the fluoride nanocrystals. The narrowing of the XRD bands observed after the heat treatment at higher temperature suggests the increase of the size of fluoride crystals. 
Photographs of the glass ceramics are presented in Fig. 10.

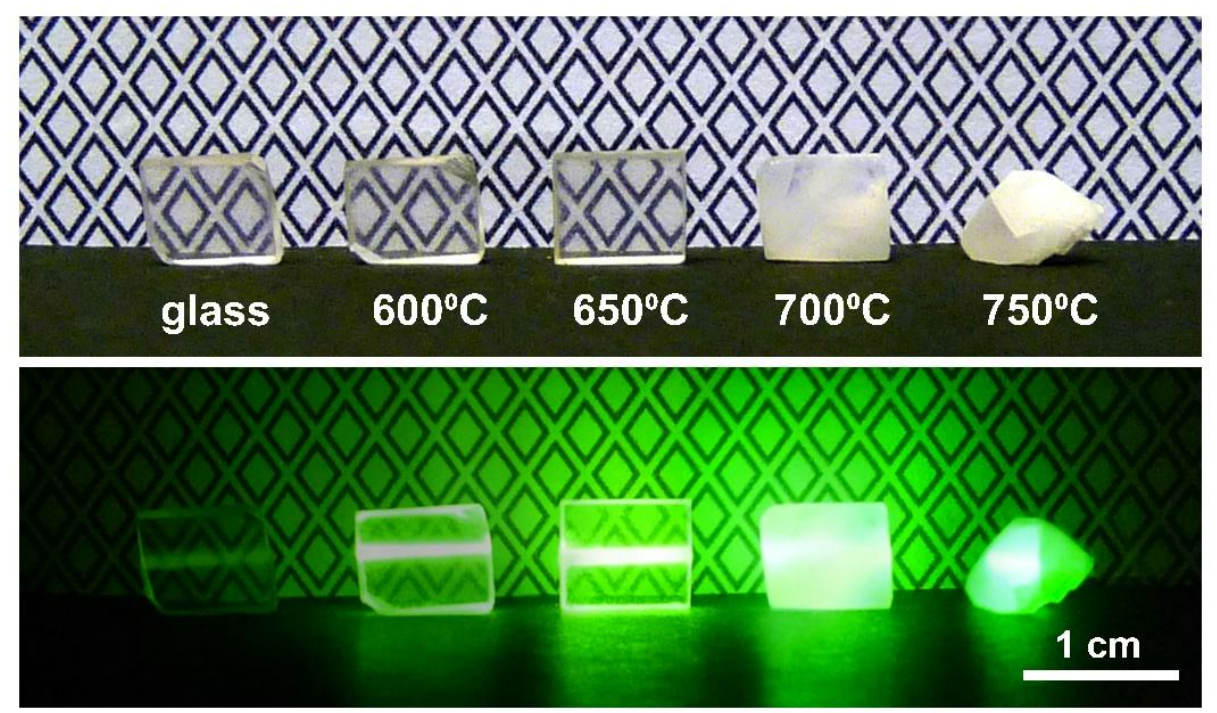

Fig. 10. Photographs of the glass and glass ceramics doped with $1 \mathrm{~mol} \% \mathrm{ErF}_{3}$ obtained by the heat treatment at different temperatures: upper row - as prepared, lower row - excited with $975 \mathrm{~nm}$ CW laser.

Despite the crystallization of fluorides, the glass ceramics remain highly transparent after the heat treatment up to $650^{\circ} \mathrm{C}$ for $5 \mathrm{~h}$, however considerable scattering can be detected after the heat treatment at $700^{\circ} \mathrm{C}$ for $5 \mathrm{~h}$ caused by the formation of relatively large (up to $100 \mathrm{~nm}$ ) $\mathrm{Ba}_{4} \mathrm{Gd}_{3} \mathrm{~F}_{17}$ nanocrystals shown in Fig. 4. Further increase of the temperature of heat treatment leads to partial melting of the glass matrix and results in the deformation of the glass ceramic samples. 


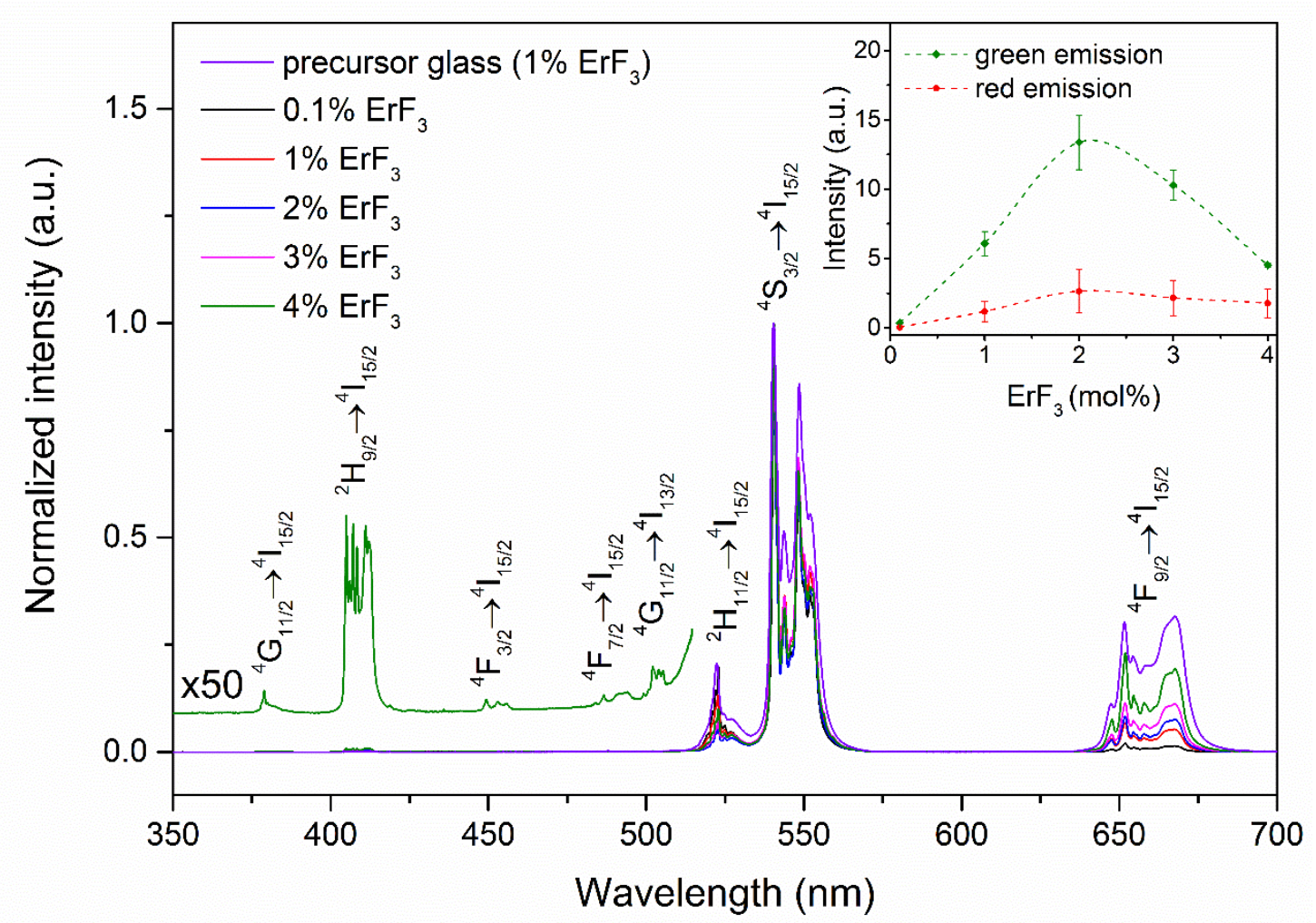

Fig. 11. UCL spectra of $\mathrm{Er}^{3+}$ ions in precursor glass and glass ceramics heat-treated at $650^{\circ} \mathrm{C}$ for $5 \mathrm{~h}$ (under $80 \mathrm{~mW} 975 \mathrm{~nm} \mathrm{CW}$ excitation). Inset: dependence of the green and red luminescence UCL intensity on $\mathrm{ErF}_{3}$ content in the glass ceramics.

Fig. 11 represents UCL spectra of $\mathrm{Er}^{3+}$ ions in the precursor glass (doped with $1 \% \mathrm{ErF}_{3}$ ) and glass ceramics heat-treated at $650^{\circ} \mathrm{C}$ for $5 \mathrm{~h}$. Sharp luminescence bands characteristic to erbium ions located in the crystalline phase were detected for both glass and glass ceramics indicating the incorporation of $\mathrm{Er}^{3+}$ ions in the crystalline environment. Slightly broader luminescence bands of the base glass suggest that a considerable fraction of $\mathrm{Er}^{3+}$ ions are located also in the amorphous environment. The most intense emission bands in the visible part of the spectrum are assigned to ${ }^{2} \mathrm{H}_{11 / 2} \rightarrow{ }^{4} \mathrm{I}_{15 / 2}(520 \mathrm{~nm}),{ }^{4} \mathrm{~S}_{3 / 2} \rightarrow{ }^{4} \mathrm{I}_{15 / 2}(545 \mathrm{~nm})$, and ${ }^{4} \mathrm{~F}_{9 / 2} \rightarrow{ }^{4} \mathrm{I}_{15 / 2}(655 \mathrm{~nm})$ transitions, respectively, characteristic of two photon UCL in $\mathrm{Er}^{3+}$ doped materials. Several additional low intensity luminescence bands in the violet and blue spectra are assigned to electronic transitions from ${ }^{4} \mathrm{G}_{11 / 2},{ }^{2} \mathrm{H}_{9 / 2},{ }^{4} \mathrm{~F}_{3 / 2}$ and ${ }^{4} \mathrm{~F}_{7 / 2}$. The population of these states can be accomplished by three photon upconversion and the luminescence from these states is usually observed in the hosts with low phonon energy. 


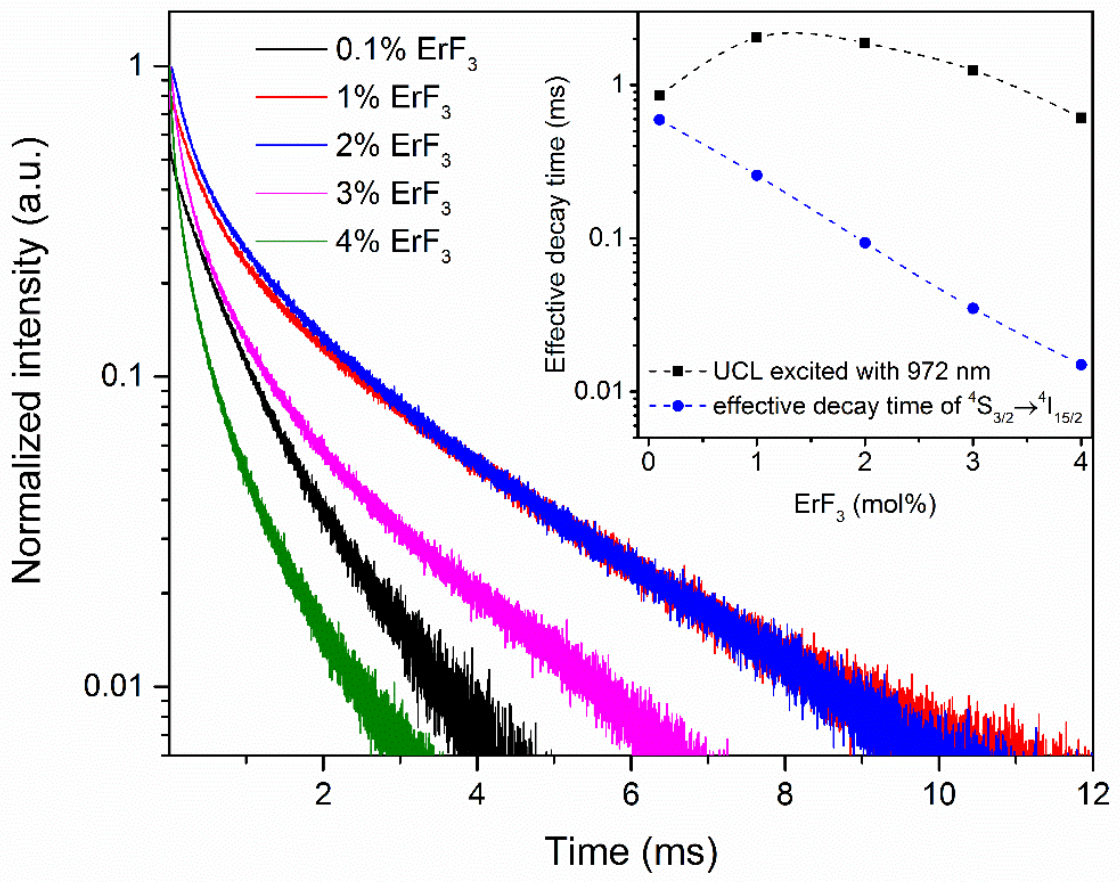

Fig. 12. Luminescence decay curves of $\mathrm{Er}^{3+}$ green emission (monitored at $545 \mathrm{~nm}$, excited at $972 \mathrm{~nm}$ ) in the glass ceramics heat treated at $650^{\circ} \mathrm{C}$ for $5 \mathrm{~h}$ doped with $0.1-4 \% \mathrm{ErF}_{3}$. Inset: Effective decay time of the green emission excited at $972 \mathrm{~nm}$ and $486 \mathrm{~nm}$.

Fig. 12 shows UCL decay curves of the green emission $\left({ }^{4} S_{3 / 2} \rightarrow{ }^{4} I_{15 / 2}\right)$ of erbium ions in the glass ceramics heat treated at $650^{\circ} \mathrm{C}$ for $5 \mathrm{~h}$. For the glass ceramics doped with $0.1 \mathrm{ErF}_{3}$ the effective decay time is almost the same as for the ${ }^{4} \mathrm{~S}_{3 / 2}$ emitting state measured under direct excitation (inset of Fig. 12), suggesting that the main UCL mechanism is excited state absorption (ESA) - a sequential absorption of two infrared photons in a single erbium ion. With the increase of $\mathrm{ErF}_{3}$ content in glasses, more erbium ions are incorporated in the crystalline phase; as the result, the average distance between $\mathrm{Er}^{3+}$ ions becomes shorter and the probability of ET between the ions is enhanced. Indeed, the increase of the effective decay time of the green UCL band suggests the involvement of ET mechanism in the UCL process [16]. When $\mathrm{ErF}_{3}$ content is further increased, the effective decay time of the green emitting state becomes shorter while green-to-red intensity ratio increases, indicating the appearance of non-radiative decay channels.

The possible UCL mechanisms of these materials are summarized in the energy level scheme of $\mathrm{Er}^{3+}$ shown in Fig. 13. In the case of glass ceramics with low $\mathrm{Er}^{3+}$ content $(0.1 \mathrm{~mol} \%)$ irradiated by $972 \mathrm{~nm}$ resonant to ${ }^{4} \mathrm{I}_{11 / 2}$, individual erbium ions are excited to ${ }^{4} \mathrm{~F}_{7 / 2}$ by ESA followed by fast de-excitation to ${ }^{4} \mathrm{~S}_{3 / 2}$ and thermally populated ${ }^{2} \mathrm{H}_{11 / 2}$. Due to the large energy gap of approximately $3000 \mathrm{~cm}^{-1}$ between ${ }^{4} \mathrm{~S}_{3 / 2}$ and ${ }^{4} \mathrm{~F}_{9 / 2}$ the decay from the green emitting state in the crystalline phase is predominantly radiative. However, in the base glass the relatively intense red emission can be caused by enhanced non-radiative relaxations between these emitting states. 
When erbium content is increased, ET processes (ET1 and ET2) dominate leading to intense visible UCL emission from the violet to red section of spectra. The population of ${ }^{4} \mathrm{G}_{11 / 2},{ }^{2} \mathrm{H}_{9 / 2}$, and ${ }^{4} \mathrm{~F}_{3 / 2}$ is realized by non-radiative multiphonon relaxation from ${ }^{2} \mathrm{G}_{7 / 2}$.

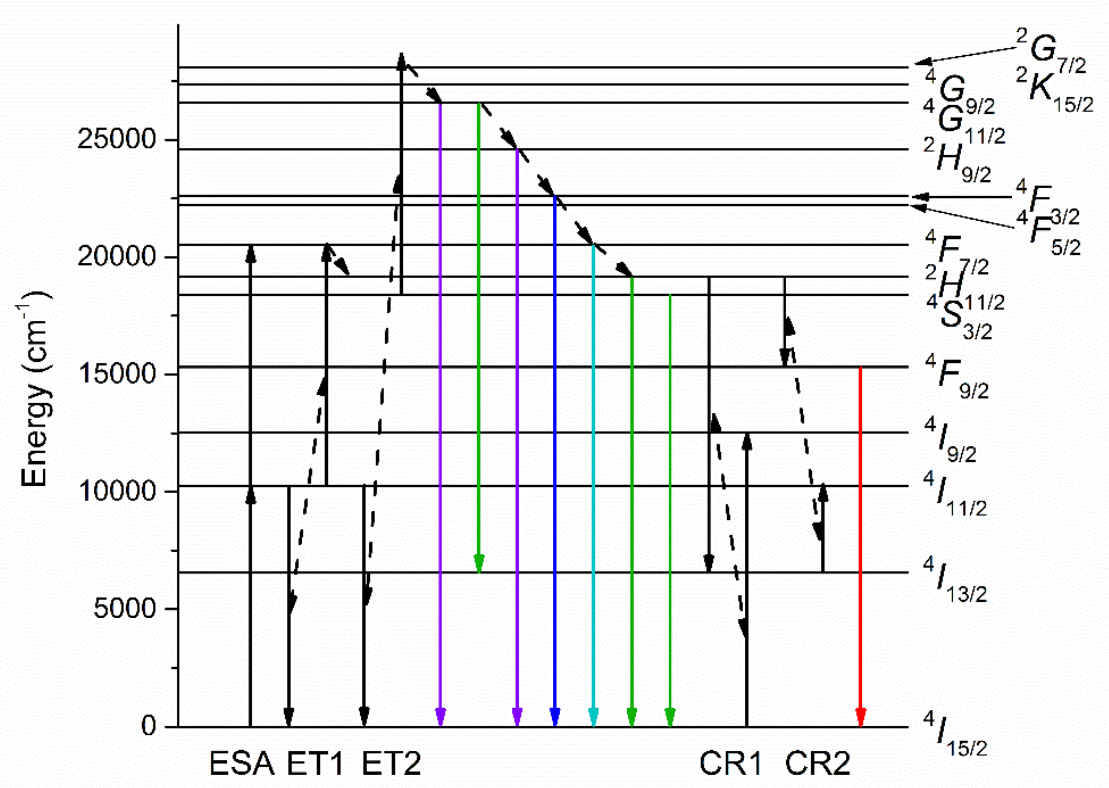

Fig. 13. Partial energy level scheme of $\mathrm{Er}^{3+}$ ions.

The intensity of the both green and red UCL bands changes when the $\mathrm{ErF}_{3}$ content is varied (see inset of Fig. 11). Two competing processes determine the efficiency of UCL - energy transfer (ET) and CR. Both processes depend on the distances between $\mathrm{Er}^{3+}$ ions, as the result the content of $\mathrm{ErF}_{3}$ has to be carefully adjusted. The maximum intensity of UCL was observed for the glass ceramics containing $2 \mathrm{~mol}_{\mathrm{O} \mathrm{ErF}_{3}}$; further concentration increase leaded to a rapid decline of the UCL intensity indicating enhancement of the CR efficiency (see inset of Fig. 12). Additionally a slight decrease of green-to-red luminescence intensity ratio can be observed when $\mathrm{ErF}_{3}$ content is increased. Such behavior is characteristic to $\mathrm{CR}$ in $\mathrm{Er}^{3+}$ doped materials. Several CR mechanisms leading to increased population of ${ }^{4} \mathrm{~F}_{9 / 2}$ can be considered: CR1: ${ }^{2} \mathrm{H}_{11 / 2},{ }^{4} \mathrm{~S}_{3 / 2}+{ }^{4} \mathrm{I}_{15 / 2} \rightarrow{ }^{4} \mathrm{I}_{13 / 2}+{ }^{4} \mathrm{I}_{9 / 2}$ followed by CR2: ${ }^{2} \mathrm{H}_{11 / 2},{ }^{4} \mathrm{~S}_{3 / 2}+{ }^{4} \mathrm{I}_{13 / 2} \rightarrow{ }^{4} \mathrm{~F}_{9 / 2}+{ }^{4} \mathrm{I}_{11 / 2}$.

In general ET is favorable for UCL because the efficiency of ET is expected to be several orders of magnitude higher than ESA [1], however when the distances between $\mathrm{Er}^{3+}$ ions are short enough (corresponding to the content of $\mathrm{ErF}_{3}$ more than $2 \mathrm{~mol} \%$ ), despite the enhancement of ET, a rapid increase of non-radiative decay channels leads to a decrease of both decay time and luminescence intensity. 


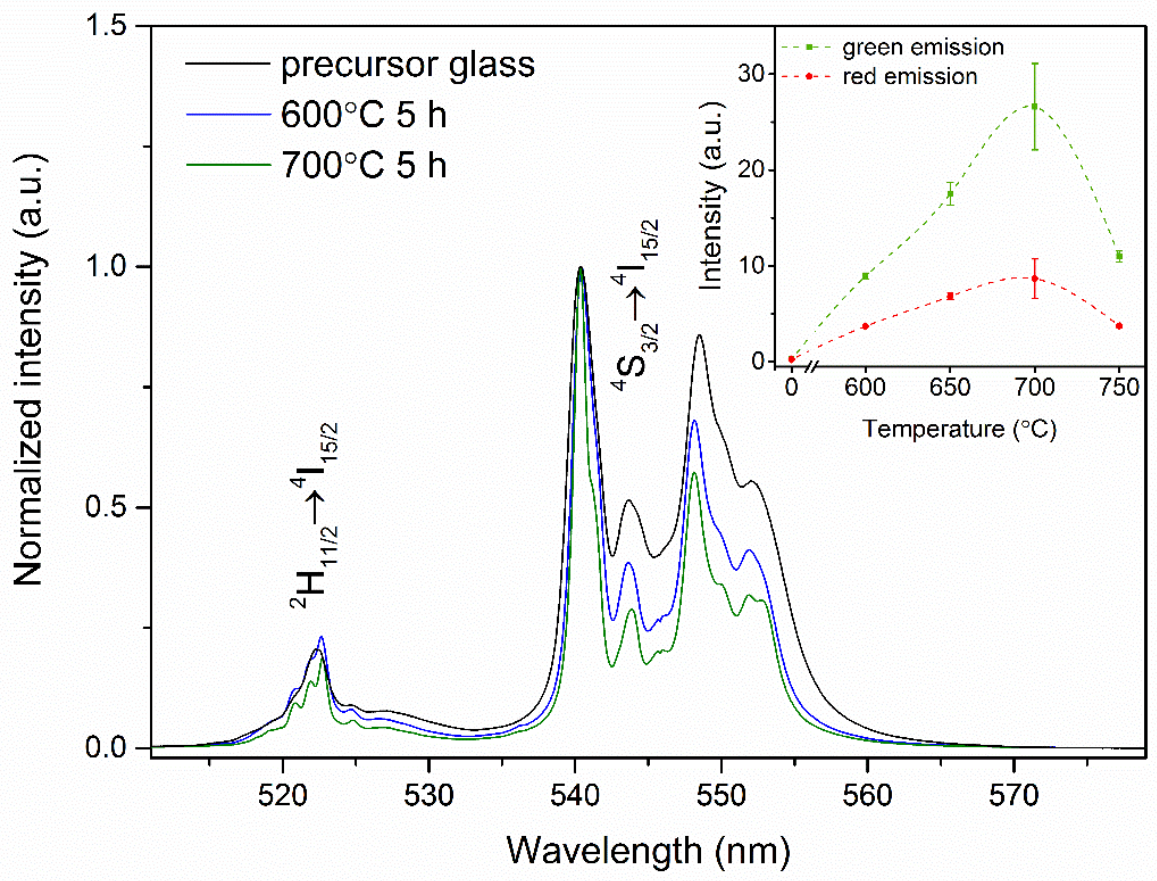

Fig. 14. UCL spectra of $\mathrm{Er}^{3+}$ ions in the base glass and glass ceramics heat-treated at $600^{\circ} \mathrm{C}$ and $700^{\circ} \mathrm{C}$ for $5 \mathrm{~h}$ doped with $2 \% \mathrm{ErF}_{3}$. Inset: UCL intensity of green and red luminescence bands for the samples heat treated at different temperatures.

The UCL intensity of glass ceramics is approximately two orders of magnitude higher in comparison to the base glass due to the incorporation of $\mathrm{Er}^{3+}$ ions in the low phonon environment of fluoride nanocrystals (see Fig. 14). Interestingly, more than twofold enhancement of the UCL intensity with the increase of the temperature of heat treatment from $600^{\circ} \mathrm{C}$ to $700^{\circ} \mathrm{C}$ is observed. In addition, slight changes in the luminescence bands can be observed when the temperature of the heat treatment is varied, which is an indication of the alteration of the local environment of $\mathrm{Er}^{3+}$. In order to investigate the origin of these deviations, the luminescence properties of single phase $\mathrm{Er}^{3+}$ doped $\mathrm{Ba}_{4} \mathrm{Gd}_{3} \mathrm{~F}_{17}$ were investigated. 


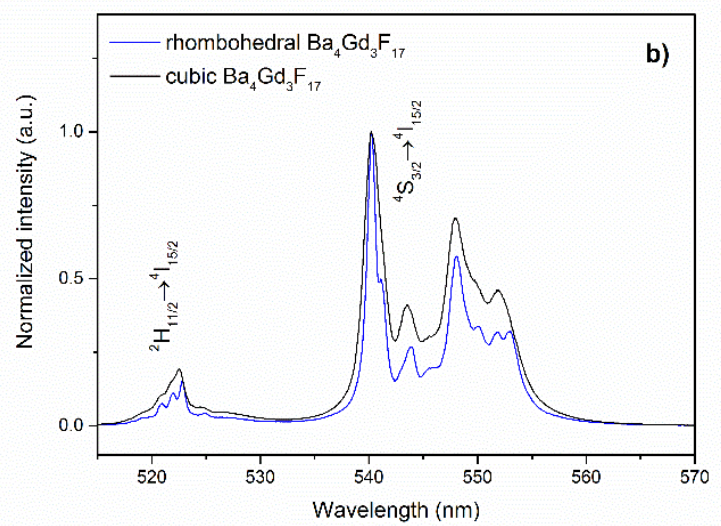

Fig. 15. a) Excitation spectra (exciting ${ }^{4} \mathrm{~F}_{7 / 2}$, measuring green emission) and b) green emission spectra (excited with $486 \mathrm{~nm}$ ) of $\mathrm{Er}^{3+}$ ions in cubic and rhombohedral $\mathrm{Ba}_{4} \mathrm{Gd}_{3} \mathrm{~F}_{17}: \mathrm{Er}^{3+}$.

Fig. 15 shows a comparison of excitation and luminescence spectra of the cubic and rhombohedral $\mathrm{Ba}_{4} \mathrm{Gd}_{3} \mathrm{~F}_{17}: 0.5 \mathrm{ErF}_{3}$. The excitation and luminescence spectra are alike for the both polymorphs suggesting similar environment of $\mathrm{Er}^{3+}$ ions in the crystalline lattice. Nevertheless, the spectra of rhombohedral phase exhibit distinct narrow excitation and luminescence bands whereas the cubic phase reveals broader and less-resolved bands characteristic of disordered structure. The broadening of the luminescence bands often originate from the multisite formation in the crystalline or amorphous material. At low temperature and in the absence of energy transfer, $\mathrm{Er}^{3+}$ ions at different sites in the crystalline lattice can be selectively excited and detected [44]. The low-temperature (10 K) luminescence spectra of cubic and rhombohedral $\mathrm{Ba}_{4} \mathrm{Gd}_{3} \mathrm{~F}_{17}$ are shown in Fig. 16.
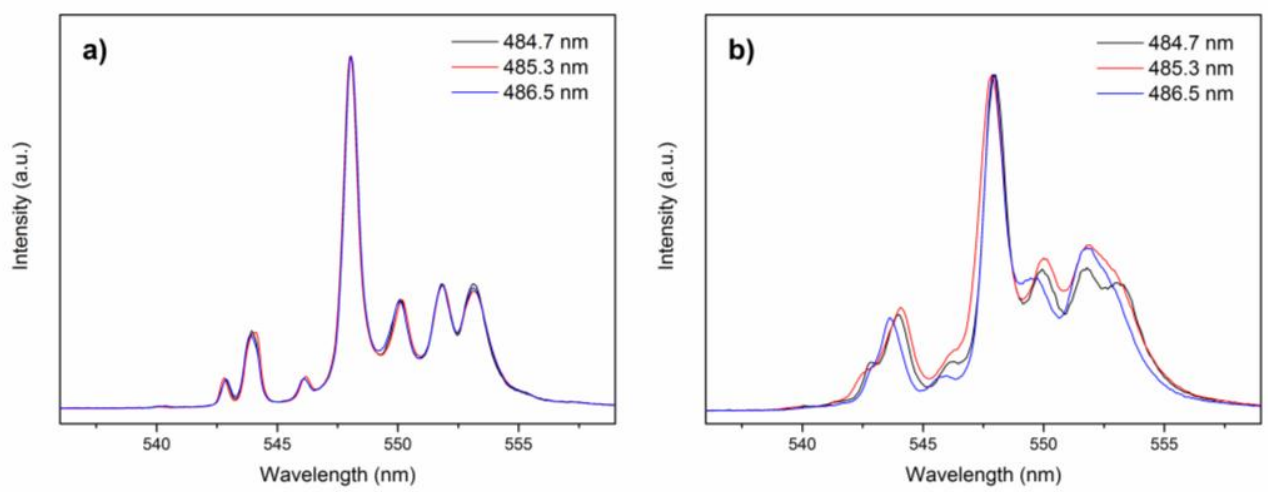

Fig. 16. Luminescence spectra of $\mathrm{Er}^{3+}$ ions in a) rhombohedral and b) cubic $\mathrm{Ba}_{4} \mathrm{Gd}_{3} \mathrm{~F}_{17}$ detected at $10 \mathrm{~K}$.

No considerable changes in the luminescence spectra were observed for the rhombohedral $\mathrm{Ba}_{4} \mathrm{Gd}_{3} \mathrm{~F}_{17}$ when the wavelength of the excitation source was varied (see Fig. 16.a), indicating incorporation of $\mathrm{Er}^{3+}$ ions in the identic environment. This phenomenon has been observed also in $\mathrm{Ba}_{4} \mathrm{Y}_{3} \mathrm{~F}_{17}$ containing glass ceramics reported previously [28]. We can assume that $\mathrm{Er}^{3+}$ replace $\mathrm{Gd}^{3+}$ ions in the $\mathrm{RE}^{3+}$ cationic positions with $\mathrm{C}_{1}$ symmetry. In the cubic $\mathrm{Ba}_{4} \mathrm{Gd}_{3} \mathrm{~F}_{17}$ sample slight changes in the luminescence spectra can be detected suggesting that erbium ions 
are incorporated in similar but not identic cationic positions. We assume that similarly to the rhombohedral phase in cubic $\mathrm{Ba}_{4} \mathrm{Gd}_{3} \mathrm{~F}_{17} \mathrm{Er}^{3+}$ replace $\mathrm{Gd}^{3+}$ ions located in $\mathrm{Ba}_{8} \mathrm{Gd}_{6} \mathrm{~F}_{68}$ structural units and the multisite formation is caused by distortion of the relative positions of these units in relation to one another.

Due to the different local environment of $\mathrm{Er}^{3+}$ ions in cubic and rhombohedral $\mathrm{Ba}_{4} \mathrm{Gd}_{3} \mathrm{~F}_{17}$, both luminescence and luminescence excitation spectra can be used to distinguish cubic and rhombohedral polymorphs in the glass ceramics.
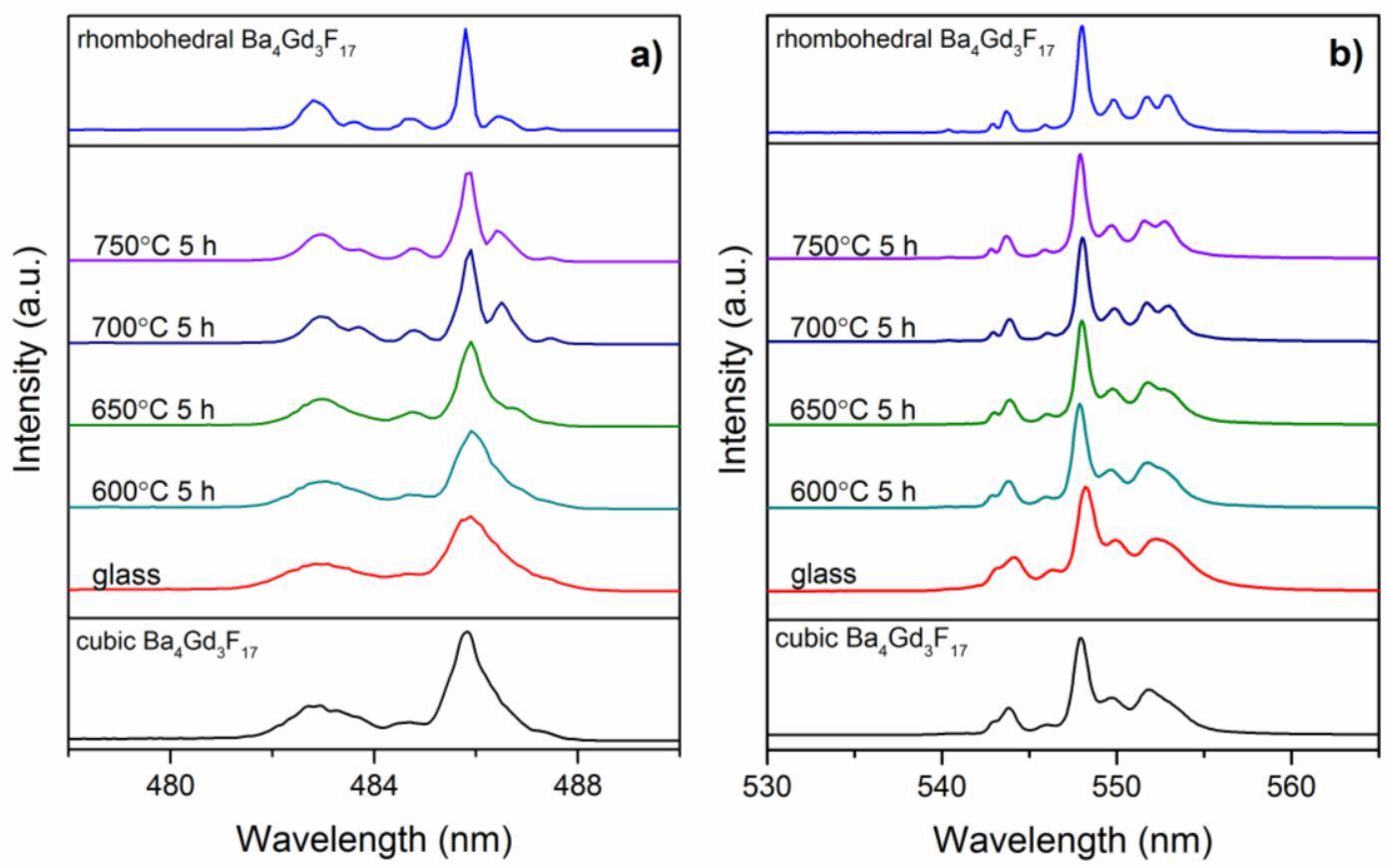

Fig. 17. a) Excitation spectra (exciting ${ }^{4} \mathrm{~F}_{7 / 2}$, detecting green emission) and b) emission spectra (excited with $486 \mathrm{~nm}$ ) of $\mathrm{Er}^{3+}$ ions in glass ceramics doped with $0.1 \% \mathrm{ErF}_{3}$ compared with the polycrystalline cubic and rhombohedral $\mathrm{Ba}_{4} \mathrm{Gd}_{3} \mathrm{~F}_{17}$ polycrystalline material measured at $10 \mathrm{~K}$.

In Fig. 17 the evolution of excitation and luminescence spectra of $\mathrm{Er}^{3+}$ ions in the glass and glass ceramics is shown. It should be noted that a small fraction of cubic nanocrystals are present in the glass sample (see Fig. 2 and Fig. 3), as the result luminescence spectra of as prepared glasses closely resemble glass ceramics. At $10 \mathrm{~K}$ both luminescence and luminescence excitation spectra of the glass and glass ceramics heat treated at $600^{\circ} \mathrm{C}$ for $5 \mathrm{~h}$ resemble features characteristic to the cubic $\mathrm{Ba}_{4} \mathrm{Gd}_{3} \mathrm{~F}_{17}$. However, when the temperature of the heat treatment is increased, slight changes in both luminescence and luminescence excitation spectra can be detected suggesting a change in the local environment of the erbium ions. Both luminescence and luminescence excitation spectra became similar to the rhombohedral $\mathrm{Ba}_{4} \mathrm{Gd}_{3} \mathrm{~F}_{17}$ indicating a phase transition from cubic to rhombohedral polymorph. These results suggest that a phase transition from the metastable cubic to the ordered rhombohedral phase takes place in the temperature range $650-700^{\circ} \mathrm{C}$ and $\mathrm{Er}^{3+}$ ions are not only efficient activator 
for UCL but also a useful and precise structural probe for the analysis of phase transitions in such complex systems as oxyfluoride glass ceramics.

\section{Conclusions}

For the first time transparent erbium doped glass ceramics containing $\mathrm{Ba}_{4} \mathrm{Gd}_{3} \mathrm{~F}_{17}$ nanocrystals were prepared. The unit cell parameters and atomic positions of the two polymorphic modifications of $\mathrm{Ba}_{4} \mathrm{Gd}_{3} \mathrm{~F}_{17}$ synthesized by co-precipitation and thermal treatment were found to be in a good agreement with cubic fluorite-type (Fm $\overline{3} \mathrm{~m})$ and rhombohedrally distorted

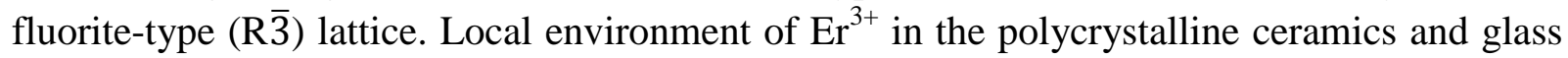
ceramics was analyzed. In the temperature range of $650-700^{\circ} \mathrm{C}$, a phase transition from metastable cubic to rhombohedrally distorted fluorite phase in the glass ceramics was observed.

An efficient UCL resulting from ET between erbium ions was observed under near-infrared excitation $(972 \mathrm{~nm})$. The intensity of the UCL in the glass ceramics with rhombohedral $\mathrm{Ba}_{4} \mathrm{Gd}_{3} \mathrm{~F}_{17}$ nanocrystals was two orders of magnitude higher than in the precursor glass and at least two times higher than in the cubic phase.

In conclusion, low local symmetry of $\mathrm{RE}^{3+}\left(\mathrm{C}_{1}\right)$ and low effective phonon energy $\left(310 \mathrm{~cm}^{-1}\right)$ of rhombohedral $\mathrm{Ba}_{4} \mathrm{Gd}_{3} \mathrm{~F}_{17}$ nanocrystals make this glass ceramics a desirable host for UCL applications.

\section{Acknowledgments}

This work was supported by National Research Program IMIS ${ }^{2}$. This research is being implemented thanks to Arnis Riekstins "MikroTik" donation. Donations are administered by the University of Latvia Foundation.

\section{References}

[1] F. Auzel, Upconversion and Anti-Stokes Processes with $\mathrm{f}$ and d Ions in Solids, Chem. Rev. 104 (2004) 139-174. doi:10.1021/cr020357g.

[2] R. Scheps, Upconversion laser processes, Prog. Quantum Electron. 20 (1996) 271-358. doi:10.1016/0079-6727(95)00007-0.

[3] H. Scheife, G. Huber, E. Heumann, S. Bär, E. Osiac, Advances in up-conversion lasers based on $\mathrm{Er}^{3+}$ and $\mathrm{Pr}^{3+}$, Opt. Mater. (Amst). 26 (2004) 365-374. doi:10.1016/j.optmat.2003.10.010.

[4] M. Lin, Y. Zhao, S. Wang, M. Liu, Z. Duan, Y. Chen, F. Li, F. Xu, T. Lu, Recent advances in synthesis and surface modification of lanthanide-doped upconversion nanoparticles for biomedical applications, Biotechnol. Adv. 30 (2012) 1551-1561. doi:10.1016/j.biotechadv.2012.04.009.

[5] M. Wang, G. Abbineni, A. Clevenger, C. Mao, S. Xu, Upconversion nanoparticles: synthesis, surface modification and biological applications, Nanomedicine 
Nanotechnology, Biol. Med. 7 (2011) 710-729. doi:10.1016/j.nano.2011.02.013.

[6] H.H. Refai, Static Volumetric Three-Dimensional Display, J. Disp. Technol. 5 (2009) 391-397. doi:10.1109/JDT.2009.2027911.

[7] E. Downing, L. Hesselink, J. Ralston, R. Macfarlane, A Three-Color, Solid-State, Three-Dimensional Display, Science. $273 \quad$ (1996) 1185-1189. doi:10.1126/science.273.5279.1185.

[8] S. Zhou, S. Jiang, X. Wei, Y. Chen, C. Duan, M. Yin, Optical thermometry based on upconversion luminescence in $\mathrm{Yb}^{3+} / \mathrm{Ho}^{3+}$ co-doped $\mathrm{NaLuF}_{4}$, J. Alloys Compd. 588 (2014) 654-657. doi:10.1016/j.jallcom.2013.11.132.

[9] H.S. Mader, O.S. Wolfbeis, Optical Ammonia Sensor Based on Upconverting Luminescent Nanoparticles, Anal. Chem. $82 \quad$ (2010) 5002-5004. doi:10.1021/ac1007283.

[10] Y. Chen, W. He, Y. Jiao, H. Wang, X. Hao, J. Lu, S. Yang, $\beta-\mathrm{NaYF}_{4}: \mathrm{Er}^{3+}(10 \%)$ microprisms for the enhancement of a-Si:H solar cell near-infrared responses, J. Lumin. 132 (2012) 2247-2250. doi:10.1016/j.jlumin.2012.04.011.

[11] A. Shalav, B.S. Richards, M.A. Green, Luminescent layers for enhanced silicon solar cell performance: Up-conversion, Sol. Energy Mater. Sol. Cells. 91 (2007) 829-842. doi:10.1016/j.solmat.2007.02.007.

[12] C. Zhang, H.-P. Zhou, L.-Y. Liao, W. Feng, W. Sun, Z.-X. Li, C.-H. Xu, C.-J. Fang, L.D. Sun, Y.-W. Zhang, C.-H. Yan, Luminescence Modulation of Ordered Upconversion Nanopatterns by a Photochromic Diarylethene: Rewritable Optical Storage with Nondestructive Readout, Adv. Mater. 22 (2010) 633-637. doi:10.1002/adma.200901722.

[13] F. Wang, X. Liu, Recent advances in the chemistry of lanthanide-doped upconversion nanocrystals, Chem. Soc. Rev. 38 (2009) 976-989. doi:10.1039/b809132n.

[14] J.C. Goldschmidt, S. Fischer, Upconversion for Photovoltaics - a Review of Materials, Devices and Concepts for Performance Enhancement, Adv. Opt. Mater. 3 (2015) 510535. doi:10.1002/adom.201500024.

[15] A. Polman, Erbium as a probe of everything?, Phys. B Condens. Matter. 300 (2001) 7890. doi:10.1016/S0921-4526(01)00573-7.

[16] J.F. Suyver, A. Aebischer, D. Biner, P. Gerner, J. Grimm, S. Heer, K.W. Krämer, C. Reinhard, H.U. Güdel, Novel materials doped with trivalent lanthanides and transition metal ions showing near-infrared to visible photon upconversion, Opt. Mater. (Amst). 27 (2005) 1111-1130. doi:10.1016/j.optmat.2004.10.021.

[17] D.N. Patel, R.B. Reddy, S.K. Nash-Stevenson, Diode-pumped violet energy upconversion in $\mathrm{BaF}_{2}: \mathrm{Er}^{3+}$, Appl. Opt. 37 (1998) 7805-7808. doi:10.1364/AO.37.007805.

[18] B.P. Sobolev, N.L. Tkachenko, Phase diagrams of $\mathrm{BaF}_{2}-(\mathrm{Y}, \mathrm{Ln}) \mathrm{F}_{3}$ systems, J. Less Common Met. 85 (1982) 155-170. doi:10.1016/0022-5088(82)90067-4. 
[19] M.P. Miller, J.C. Wright, Single site multiphonon and energy transfer relaxation phenomena in $\mathrm{BaF}_{2}: \mathrm{Er}^{3+}$, J. Chem. Phys. 68 (1978) 1548-1562. doi:10.1063/1.435924.

[20] F. Cornacchia, D. Parisi, C. Bernardini, A. Toncelli, M. Tonelli, Efficient, diodepumped $\mathrm{Tm}^{3+}: \mathrm{BaY}_{2} \mathrm{~F}_{8}$ vibronic laser, Opt. Express. 12 (2004) 1982-1989. doi:10.1364/OPEX.12.001982.

[21] N. Coluccelli, D. Gatti, G. Galzerano, F. Cornacchia, D. Parisi, A. Toncelli, M. Tonelli, P. Laporta, Tunability range of $245 \mathrm{~nm}$ in a diode-pumped $\mathrm{Tm}: \mathrm{BaY}_{2} \mathrm{~F}_{8}$ laser at $1.9 \mu \mathrm{m}$ : a theoretical and experimental investigation, Appl. Phys. B. 85 (2006) 553-555. doi:10.1007/s00340-006-2347-2.

[22] C. Chen, C. Li, L. Zhao, X. Liu, T. Bai, H. Huang, Z. Shi, S. Feng, A facile synthesis of water-soluble $\mathrm{BaYF}_{5}: \mathrm{Ln}^{3+} \mathrm{NCs}$ with excellent luminescent properties as promising contrast agent for dual-modal bioimaging, Inorg. Chem. Commun. 62 (2015) 11-14. doi:10.1016/j.inoche.2015.10.020.

[23] D. Yang, Y. Dai, J. Liu, Y. Zhou, Y. Chen, C. Li, P. Ma, J. Lin, Ultra-small BaGdF5based upconversion nanoparticles as drug carriers and multimodal imaging probes, Biomaterials. 35 (2014) 2011-2023. doi:10.1016/j.biomaterials.2013.11.018.

[24] H.K. Dan, D. Zhoua, W. Rongfei, T.M. Hau, Q. Jiao, X. Yu, J. Qiu, Up-conversion of $\mathrm{Er}^{3+} / \mathrm{Yb}^{3+}$ co-doped transparent glass-ceramics containing $\mathrm{Ba}_{2} \mathrm{LaF}_{7}$ nanocrystals, J. Rare Earths. 31 (2013) 843-848. doi:10.1016/S1002-0721(12)60368-8.

[25] F. Liu, Y. Wang, D. Chen, Y. Yu, E. Ma, L. Zhou, P. Huang, Upconversion emission of a novel glass ceramic containing $\mathrm{Er}^{3+}: \mathrm{BaYF}_{5}$ nano-crystals, Mater. Lett. 61 (2007) 5022-5025. doi:10.1016/j.matlet.2007.03.089.

[26] S. Jiang, H. Guo, X. Wei, C. Duan, M. Yin, Enhanced upconversion in $\mathrm{Ho}^{3+}$-doped transparent glass ceramics containing $\mathrm{BaYbF}_{5}$ nanocrystals, J. Lumin. 152 (2014) 195198. doi:10.1016/j.jlumin.2013.11.030.

[27] Y. Fei, S. Zhao, X. Sun, L. Huang, D. Deng, S. Xu, Preparation and optical properties of $\mathrm{Eu}^{3+}$ doped and $\mathrm{Er}^{3+} / \mathrm{Yb}^{3+}$ codoped oxyfluoride glass ceramics containing $\mathrm{Ba}_{1-\mathrm{x}} \mathrm{Lu}_{\mathrm{x}} \mathrm{F}_{2+\mathrm{x}}$ nanocrystals, J. Non. Cryst. Solids. 428 (2015) 20-25. doi:10.1016/j.jnoncrysol.2015.08.004.

[28] G. Krieke, A. Sarakovskis, Crystallization and upconversion luminescence of distorted fluorite nanocrystals in $\mathrm{Ba}^{2+}$ containing oxyfluoride glass ceramics, J. Eur. Ceram. Soc. 36 (2016) 1715-1722. doi:10.1016/j.jeurceramsoc.2016.01.025.

[29] S. V Kuznetsov, P.P. Fedorov, V. V Voronov, K.S. Samarina, R.P. Ermakov, V. V Osiko, Synthesis of $\mathrm{Ba}_{4} \mathrm{R}_{3} \mathrm{~F}_{17}$ ( $\mathrm{R}$ stands for rare-earth elements) powders and transparent compacts on their base, Russ. J. Inorg. Chem. 55 (2010) 484-493. doi:10.1134/S0036023610040029.

[30] N. Doebelin, R. Kleeberg, Profex : a graphical user interface for the Rietveld refinement program BGMN, J. Appl. Crystallogr. 48 (2015) 1573-1580. doi:10.1107/S1600576715014685.

[31] B.A. Maksimov, K. Solans, A.P. Dudka, E.A. Genkina, M. Font-Badria, I.I. 
Buchinskaya, A.A. Loshmanov, A.M. Golubev, V.I. Simonov, M. Font-Altaba, others, The fluorite-matrix-based $\mathrm{Ba}_{4} \mathrm{R}_{3} \mathrm{~F}_{17}(\mathrm{R}=\mathrm{Y}, \mathrm{Yb})$ crystal structure. Ordering of cations and specific features of the anionic motif, Crystallogr. REPORTS. 41 (1996) 50-57.

[32] K. Momma, F. Izumi, VESTA 3 for three-dimensional visualization of crystal, volumetric and morphology data, J. Appl. Crystallogr. 44 (2011) 1272-1276. doi:10.1107/S0021889811038970.

[33] P.P. Fedorov, A.A. Luginina, A.I. Popov, Transparent oxyfluoride glass ceramics, J. Fluor. Chem. 172 (2015) 22-50. doi:10.1016/j.jfluchem.2015.01.009.

[34] a. de Pablos-Martin, C. Patzig, T. Höche, A. Duran, M.J. Pascual, Distribution of thulium in $\mathrm{Tm}^{3+}$-doped oxyfluoride glasses and glass-ceramics, CrystEngComm. 15 (2013) 6979-6985. doi:10.1039/c3ce40731d.

[35] S. Bhattacharyya, C. Bocker, T. Heil, J.R. Jinschek, T. Höche, C. Rüssel, H. Kohl, Experimental Evidence of Self-Limited Growth of Nanocrystals in Glass, Nano Lett. 9 (2009) 2493-2496. doi:10.1021/n1901283r.

[36] a. de Pablos-Martín, G.C. Mather, F. Muñoz, S. Bhattacharyya, T. Höche, J.R. Jinschek, T. Heil, A. Durán, M.J. Pascual, Design of oxy-fluoride glass-ceramics containing $\mathrm{NaLaF}_{4}$ nano-crystals, J. Non. Cryst. Solids. 356 (2010) 3071-3079. doi:10.1016/j.jnoncrysol.2010.04.057.

[37] P.P. Fedorov, Association of point defects in non-stoichiometric $\mathrm{M}_{1-\mathrm{x}} \mathrm{R}_{\mathrm{x}} \mathrm{F}_{2+\mathrm{x}}$ fluoritetype solid solutions, Butll. Soc. Cat. Cien. XII (1991) 349-381.

[38] N.I. Sorokin, A.M. Golubev, B.P. Sobolev, Structural mechanisms of superionic conductivity in $\mathrm{M}_{1-x} \mathrm{R}_{\mathrm{x}} \mathrm{F}_{2+\mathrm{x}}$ single crystals, Crystallogr. Reports. 59 (2014) 238-247. doi:10.1134/S1063774514010155.

[39] M. Kolesik, B. Sobolev, Raman scattering study of the $\mathrm{Ba}_{1-\mathrm{x}} \mathrm{R}_{\mathrm{x}} \mathrm{F}_{2+\mathrm{x}}$ superionic conductors, Solid State Ionics. 47 (1991) 325-329. doi:10.1016/0167-2738(91)90255A.

[40] E. Garcia, R.R. Ryan, Structure of the laser host material LiYF , Acta Crystallogr. Sect. C Cryst. Struct. Commun. 49 (1993) 2053-2054. doi:10.1107/S0108270193005876.

[41] A. Grzechnik, P. Bouvier, M. Mezouar, M.D. Mathews, A.K. Tyagi, J. Köhler, Hexagonal $\mathrm{Na}_{1.5} \mathrm{Y}_{1.5} \mathrm{~F}_{6}$ at High Pressures, J. Solid State Chem. 165 (2002) 159-164. doi:10.1006/jssc.2001.9525.

[42] L.H. Guilbert, J.Y. Gesland, A. Bulou, R. Retoux, Structure and raman spectroscopy of czochralski-grown barium yttrium and barium ytterbium fluorides crystals, Mater. Res. Bull. 28 (1993) 923-930. doi:10.1016/0025-5408(93)90039-G.

[43] C. Renero-Lecuna, R. Martín-Rodríguez, R. Valiente, J. González, F. Rodríguez, K.W. Krämer, H.U. Güdel, Origin of the High Upconversion Green Luminescence Efficiency in $\beta-\mathrm{NaYF}_{4}: 2 \% \mathrm{Er}^{3+}, \quad 20 \% \mathrm{Yb}^{3+}$, Chem. Mater. $23 \quad$ (2011) 3442-3448. doi:10.1021/cm2004227.

[44] A. Sarakovskis, G. Krieke, G. Doke, J. Grube, L. Grinberga, M. Springis, 
Comprehensive study on different crystal field environments in highly efficient $\mathrm{NaLaF}_{4}: \mathrm{Er}^{3+}$ upconversion phosphor, Opt. Mater. (Amst). 39 (2015) 90-96. doi:10.1016/j.optmat.2014.11.004. 
Fig. 1. DTA curve of glass samples containing $0.1,2$ and $4 \% \mathrm{ErF}_{3}$.

Fig. 2. XRD patterns of oxyfluoride glass doped with $0.1 \% \mathrm{ErF}_{3}$ heat treated at different temperatures for $5 \mathrm{~h}\left(*\right.$ indicate the most intensive peaks of aluminosilicate nepheline, ${ }^{\circ}$ marks an unidentified phase).

Fig. 3. SEM micrographs of a,b) glass and glass ceramics heat treated at c,d) $600^{\circ} \mathrm{C}$, e,f) $650^{\circ} \mathrm{C}$, g,h) $700^{\circ} \mathrm{C}$ and i,j) $750^{\circ} \mathrm{C}$ for $5 \mathrm{~h}$.

Fig. 4. TEM micrographs of glass ceramics heat treated at a-c) $600^{\circ} \mathrm{C}$ and d-f) $700^{\circ} \mathrm{C}$ for $5 \mathrm{~h}$.

Fig. 5. Experimental and calculated XRD patterns of $\mathrm{Ba}_{4} \mathrm{Gd}_{3} \mathrm{~F}_{17}$ after heat treatment at a) $600^{\circ} \mathrm{C}$ and b) $800^{\circ} \mathrm{C}$ for $1 \mathrm{~h}$. Insets: enlarged sections of XRD patterns.

Fig. 6. Rare earth clusters in fluorite type $\mathrm{BaF}_{2}-\mathrm{GdF}_{3}$ solid solutions.

Fig. 7. Crystal structure of rhombohedral $\mathrm{Ba}_{4} \mathrm{Gd}_{3} \mathrm{~F}_{17}$, projection along a axis.

Fig. 8. Raman spectra of cubic and rhombohedral $\mathrm{Ba}_{4} \mathrm{Gd}_{3} \mathrm{~F}_{17}$.

Fig. 9. The comparison of XRD patterns of glass ceramic heat treated at $725^{\circ} \mathrm{C}$ for $5 \mathrm{~h}$ and rhombohedral $\mathrm{Ba}_{4} \mathrm{Gd}_{3} \mathrm{~F}_{17}$. The superstructure reflections are marked with $\circ$. Inset: enlarged sections of XRD patterns.

Fig. 10. Photographs of the glass and glass ceramics doped with $1 \mathrm{~mol} \% \mathrm{ErF}_{3}$ obtained by the heat treatment at different temperatures: upper row - as prepared, lower row - excited with 975 $\mathrm{nm}$ CW laser.

Fig. 11. UCL spectra of $\mathrm{Er}^{3+}$ ions in precursor glass and glass ceramics heat-treated at $650^{\circ} \mathrm{C}$ for $5 \mathrm{~h}$ (under $80 \mathrm{~mW} 975 \mathrm{~nm} \mathrm{CW}$ excitation). Inset: dependence of the green and red luminescence UCL intensity on $\mathrm{ErF}_{3}$ content in the glass ceramics.

Fig. 12. Luminescence decay curves of $\mathrm{Er}^{3+}$ green emission (monitored at $545 \mathrm{~nm}$, excited at 972 $\mathrm{nm}$ ) in the glass ceramics heat treated at $650^{\circ} \mathrm{C}$ for $5 \mathrm{~h}$ doped with $0.1-4 \% \mathrm{ErF}_{3}$. Inset: Effective decay time of the green emission excited at $972 \mathrm{~nm}$ and $486 \mathrm{~nm}$.

Fig. 13. Partial energy level scheme of $\mathrm{Er}^{3+}$ ions.

Fig. 14. UCL spectra of $\mathrm{Er}^{3+}$ ions in the base glass and glass ceramics heat-treated at $600^{\circ} \mathrm{C}$ and $700^{\circ} \mathrm{C}$ for $5 \mathrm{~h}$ doped with $2 \% \mathrm{ErF}_{3}$. Inset: UCL intensity of green and red luminescence bands for the samples heat treated at different temperatures.

Fig. 15. a) Excitation spectra (exciting ${ }^{4} \mathrm{~F}_{7 / 2}$, measuring green emission) and b) green emission spectra (excited with $486 \mathrm{~nm}$ ) of $\mathrm{Er}^{3+}$ ions in cubic and rhombohedral $\mathrm{Ba}_{4} \mathrm{Gd}_{3} \mathrm{~F}_{17}: \mathrm{Er}^{3+}$.

Fig. 16. Luminescence spectra of $\mathrm{Er}^{3+}$ ions in a) rhombohedral and b) cubic $\mathrm{Ba}_{4} \mathrm{Gd}_{3} \mathrm{~F}_{17}$ detected at $10 \mathrm{~K}$. 
Fig. 17. a) Excitation spectra (exciting ${ }^{4} \mathrm{~F}_{7 / 2}$, detecting green emission) and b) emission spectra (excited with $486 \mathrm{~nm}$ ) of $\mathrm{Er}^{3+}$ ions in glass ceramics doped with $0.1 \% \mathrm{ErF}_{3}$ compared with the polycrystalline cubic and rhombohedral $\mathrm{Ba}_{4} \mathrm{Gd}_{3} \mathrm{~F}_{17}$ polycrystalline material measured at $10 \mathrm{~K}$.

Institute of Solid State Physics, University of Latvia as the Center of Excellence has received funding from the European Union's Horizon 2020 Framework Programme H2020-WIDESPREAD-01-2016-2017-TeamingPhase2 under grant agreement No. 739508 , project CAMART ${ }^{2}$ 